NBER WORKING PAPER SERIES

\title{
AIR POLLUTION AND INFANT HEALTH: \\ WHAT CAN WE LEARN FROM CALIFORNIA'S RECENT EXPERIENCE?
}

\author{
Janet Currie \\ Matthew Neidell \\ Working Paper 10251 \\ http://www.nber.org/papers/w10251
NATIONAL BUREAU OF ECONOMIC RESEARCH
1050 Massachusetts Avenue
Cambridge, MA 02138
January 2004

We thank Maureen Cropper, Michael Greenstone, Paul Rathouz, and Jonathan Samet as well as seminar participants at Boston University, Columbia, UC Davis, the University of Chicago, the NBER Summer Institute, Princeton and Yale for many helpful comments, and Trudy Cameron for suggesting this line of research. The authors also thank Ellen Kang for excellent research assistance. Financial support from Princeton's Center for Health and Well-Being and from the University of Chicago's Center for Integrating Statistical and Environmental Science is gratefully acknowledged. The views expressed herein are those of the authors and not necessarily those of the National Bureau of Economic Research.

(C2004 by Janet Currie and Matthew Neidell. All rights reserved. Short sections of text, not to exceed two paragraphs, may be quoted without explicit permission provided that full credit, including (C) notice, is given to the source. 
Air Pollution and Infant Health: What Can We Learn From California's Recent Experience? Janet Currie and Matthew Neidell

NBER Working Paper No. 10251

January 2004

JEL No. I18

\begin{abstract}
We examine the impact of air pollution on infant death in California over the 1990s. Our work offers several innovations: First, many previous studies examine populations subject to far greater levels of pollution. In contrast, the experience of California in the 1990 s is clearly relevant to current debates over the regulation of pollution. Second, many studies examine a few routinely monitored pollutants in isolation, generally because of data limitations. We examine four "criteria" pollutants in a common framework. Third, we develop an identification strategy based on within zip code variation in pollution levels that controls for potentially important unobserved characteristics of high pollution areas. Fourth, we use rich individual-level data to investigate effects of pollution on infant mortality, fetal deaths, low birth weight and prematurity in a common framework. We find that the reductions in carbon monoxide (CO) and particulates (PM10) over the 1990s in California saved over 1,000 infant lives. However, we find little consistent evidence of pollution effects on fetal deaths, low birth weight or short gestation.

Janet Currie

Department of Economics

UCLA

405 Hilgard Avenue

Los Angeles, CA 90095-1477

and NBER

currie@simba.sscnet.ucla.edu
\end{abstract}

Matthew Neidell

Department of Economics and CISES

University of Chicago

5734 S. Ellis Ave.

Chicago, IL 60637

mneidell@uchicago.edu 
Air quality regulations are costly to both producers and consumers, and the optimal level of pollution abatement is hotly contested. For example, in October 2002, the Bush administration joined Daimler Chrysler and General Motors in a lawsuit against Californian regulations that would have mandated that one in ten cars sold in California be "low emission" or "zero-emission" vehicles, beginning in 2003 (Doggett, 2002; New York Times, October 14, 2002). New standards for ozone and particulates were proposed by the Environmental Protection Agency (EPA) in 1997, but were held up in the courts until a Supreme Court decision in 2001 (Stafford, 2001).

Pollution abatement is often justified as something that will promote health: Yet there is still much to be learned about the specific health effects. The EPA did not include infant mortality in the primary quantitative benefit analysis of the 1990 Clean Air Act Amendments in 1999 (U.S. EPA 1999) because the weight of the scientific evidence linking infant health to air pollution was viewed as insufficient.1

This paper addresses this issue by examining the impact of air pollution on infant death in California over the 1990s. Infants are of interest for two reasons. First, policy makers and the public are highly motivated to protect these most vulnerable members of society. Second, in the case of infant death the link between cause and effect is immediate, whereas for adults, diseases today may reflect pollution exposure that occurred many years ago. 2

Our work offers several innovations over the existing literature. First, many previous studies examine populations subject to greater levels of pollution, either because they lived

\footnotetext{
${ }^{1}$ As of May 12, 2003, the EPA's Scientific Advisory Board was debating whether to include an analysis of infant health effects in its 2003 report to Congress on the benefits of the Clean Air Act. However, they had determined that "[these] estimates are not meant to be additive to the primary estimates of mortality" (U.S. EPA, 2003, page 6-13).

${ }^{2}$ California's experience is also of special interest, since under the Clean Air Act of 1970, it is the only state allowed to set automobile emission standards at a level higher than the federal standard. Other states may adopt California's
} 
further in the past or in some more heavily polluted place. In contrast, the experience of California in the 1990s is clearly relevant to the contemporary debate over pollution levels in the United States.

Second, many studies examine a few routinely monitored pollutants in isolation, generally because of data limitations. We examine four "criteria" pollutants that are commonly monitored in the U.S.: Ozone (O3), carbon monoxide (CO), particulate matter (PM10), and nitrogen dioxide (NO2). Thus our results may shed light on the important question of which pollutants are most harmful to infants.

Third, while epidemiological studies have documented correlations between pollution and poor infant outcomes, it is possible that these correlations reflect some omitted characteristics (such as differences in socio-economic status or pollution of ground water) that are correlated with both air pollution and infant health outcomes. We will control for this possibility both by including a rich set of covariates, such as whether the birth was covered by public health insurance, and by estimating models with zip code level fixed effects, which will capture any unobserved characteristics of zip codes that are unchanged over time.

Fourth, we exploit rich individual-level data to estimate linear models that approximate hazard models, where the hazard is defined either over weeks or months, and the baseline hazard is specified as a flexible non-parametric spline. The robustness of our key results suggests that they are not driven by mortality displacement (or "harvesting").

Fifth, we examine effects on infant mortality, fetal death, low birth weight and prematurity in a common framework, in order to try to determine whether pollution affects infants primarily before or after the birth. And unlike virtually all existing studies, our estimates 
of the effects on low birth weight and prematurity take the possibility of fetal selection into account.

Our estimates confirm that air pollution has a significant effect on infant mortality, even at the relatively low levels of pollution experienced in recent years. Our estimates suggest that the reductions in CO and PM10 that occurred over the 1990s saved more than 1,000 infant lives in California. However, in contrast to much of the epidemiological literature, we find little consistent evidence that pollution in the prenatal period affects birth weight, the probability of short gestation, or the risk of fetal death, at least at the levels of pollution that we observe. Finally, we show that the estimated per unit effects of pollution are similar for blacks and whites and for children of more and less educated people, and that between-zip code differences in pollution levels account for relatively little of observed between-group differences in infant mortality rates.

The rest of the paper is laid out as follows: Section II provides necessary background information about the previous literature and the ways in which pollution may affect infant health. Section III describes our data while methods are described in Section IV. Section V offers results, and Section VI ends with a discussion and conclusions.

\section{Background}

Motor vehicles are a major source of PM10, NO2, and especially of CO-as much as $90 \%$ of CO in cities comes from motor vehicle exhaust (EPA, January 1993). Carbon Monoxide is an odorless, colorless gas which is poisonous at high levels. $\mathrm{CO}$ bonds with hemoglobin more easily than oxygen, so that it reduces the body's ability to deliver oxygen to organs and tissues. Because infants are small, and many have respiratory problems in any case, CO may be particularly harmful to them. Nitrogen Dioxide is a brown, reactive gas that irritates the lungs 
and may lower resistance to respiratory infections. It is also an important precursor to particulate matter in California.

Particulate matter can take many forms, including ash and dust. It is thought that the most damage comes from the smallest particles, since they are inhaled deep into the lungs (U.S. EPA, 2003b). The mechanism through which particles harm health are controversial, however the leading theory is that they cause an inflammatory response which weakens the immune system (Seaton, et al. 1995). In infants, a weakened immune system could make them more susceptible to death from a wide range of causes. PM10 exposure could also affect the health of the mother, for example, by weakening her immune system, and hence affect the fetus.

Ozone (the major component of smog) is a highly reactive compound that damages tissue, reduces lung function, and sensitizes the lungs to other irritants. For example, exposure to $\mathrm{O} 3$ during exercise reduces lung functioning in adults, and causes symptoms such as chest pain, coughing, and pulmonary congestion. Ozone is formed through reactions between nitrogen oxides (such as NO2) and volatile organic compounds (which are found in auto emissions, among other sources) in heat and sunlight. Interestingly, ozone is not generally found in homes because it is highly reactive, and quickly reacts with household surfaces (http://www.hcsc.gc.ca/hecs-sesc/air_quality/faq.htm).

Compliance with standards for NO2 and PM10 is assessed by looking at annual means (there is a 24-hour standard for PM10 as well). Compliance with standards for O3 and CO is assessed by examining whether the level of pollution exceeded the standard over any eight-hour period during the year. These different approaches to standards suggest that the effects of NO2 and PM10 may be expected to be cumulative while the effects of $\mathrm{CO}$ and $\mathrm{O} 3$ are expected to be 
more acute. We do not examine the two other criteria pollutants, SO2 and lead, because levels are now so low that many monitors have been removed from service.

A link between air pollution and infant health has long been suspected, although the exact biological mechanisms through which it occurs are not known. We also know little about what levels of these pollutants are sufficient to affect infant mortality (death in the first year of life) or about the extent that infants are protected from the negative effects of pollution while they are in the womb.

Only some potential mechanisms have been examined. For example, it has long been known that $\mathrm{CO}$ can disturb the functioning of the placenta, that it crosses the placenta, and that it tends to concentrate in the fetus at higher levels than in the mother (Longo, 1977); it has also been shown in studies using rats that $\mathrm{CO}$ can have a negative effect on brain development (Garvey and Longo, 1978).

Other studies have examined the negative effects of chemicals that are associated with high levels of CO and PM10; since motor vehicle exhaust is a major contributor of these two monitored pollutants, these pollutants may themselves be markers for other components of exhaust such as polycyclic aromatic hydrocarbons (PAHs), acetonitrile, benzene, butadiene, and cyanide. Many of these compounds have been shown to have effects on developing fetuses in animal studies which may include retarded growth.3 Studies in humans have shown elevated levels of an enzyme induced by PAHs in women about to have preterm deliveries (Huel et al., 1993).

\footnotetext{
${ }^{3}$ The web site http://www.epa.gov/ttn/atw/hapindex.html provides a list of the chemicals present in vehicle exhaust, and evidence regarding their health effects.
} 
Many studies have demonstrated links between very severe pollution episodes and increased mortality of infants and others. For example, Logan and Glasg (1953) found dramatic increases in cardiopulmonary mortality during a killer fog that occurred in London England in 1952. Chart 1 summarizes some of the more recent studies, dividing them into two groups. The first group focuses on the link between poor infant outcomes and pollution in areas with high levels of pollution; most report negative associations between pollution and infant outcomes. 4

The second part of the chart focuses on U.S. studies, many of which also report a link between air pollution and infant health, although some do not. For example, Lipfert, Zhang, and Wyzga (2000) find that while they can replicate previous findings of a negative effect of PM10 on infant health, the result is not robust to changes in specification.

An important limitation of all of these studies is that it is possible that the observed relationships could reflect an unobserved factor that was correlated with both air pollution and child outcomes. This is likely to be a greater problem in studies such as Lui et al. (2003) that do not control for factors such as maternal education. However, it may be a problem even in studies that include such controls. Suppose for example, that areas with high levels of air pollution also tended to have high levels of water pollution. Then one might falsely conclude that air pollution was to blame for infant deaths, with potentially negative consequences for remediation efforts. Similarly, as we will show below, zip codes with high pollution have many other characteristics that may have a direct effect on infant outcomes, such as high rates of teen parenthood and low average levels of education. Many of the previous studies may be invalidated by the failure to control adequately for these characteristics.

\footnotetext{
${ }^{4}$ Note that PM10 refers to particles less than a particular size, while many of the studies reviewed in this chart discuss Total Suspended Particles or TSPs. In general one would expect TSP and PM10 to move together because
} 
Two studies by Chay and Greenstone deal with the problem of omitted confounders by focusing on "natural experiments" provided by the implementation of the Clean Air Act of 1970, and geographic variation in pollution levels induced by the recession of the early 1980 s. These studies are similar in spirit to a sequence of papers by C. Arden Pope, who investigated the health effects of the temporary closing of a Utah steel mill (Pope, 1989; Ransom and Pope, 1992; Pope, Schwartz, and Ransom, 1992) and to Friedman et al. (2001) who examine the effect of changes in traffic patterns in Atlanta due to the 1996 Olympic games. However, these studies did not look specifically at infants.

Chay and Greenstone show that on average, TSPs fell from 95 to 60 micrograms per cubic meter of air between 1970 and 1984. However, they show that both the Clean Air Act and the recession induced sharper reductions in TSPs in some areas than in others, and they use this exogenous variation in levels of pollution to identify its effects. They estimate that a one unit decline in TSPs associated with the Clean Air Act (recession) led to between five and eight (four and seven) fewer infant deaths per 100,000 live births but had little effect on the incidence of low birth weight.5

Although these studies provide compelling evidence of the link between pollution and infant health, it is not clear that reductions from the much lower levels of ambient pollution today would have the same effect. For example, it might be the case that only pollution above some threshold is harmful, and that pollution has already been reduced below that threshold. Moreover, the Chay and Greenstone studies cannot speak to whether other pollutants affect infant health, since only TSPs were measured during the time period that they study.

PM10 is a component of TSP, but some of the larger particles included in TSP may be less damaging than the particles found in PM10. 
In the current paper, we propose an alternative identification strategy using individuallevel data and exploiting within-zip code variation in pollution levels. This strategy enables us to create finer measures of pollution and to control for individual differences between mothers that may be associated with birth outcomes. As we show below, even after controlling for seasonal effects and weather, there is a great deal of within-zip code variation in pollution levels. The zip code fixed effects control for many factors (such as poverty) which are both strongly geographically concentrated, and associated with poorer prospects for infants. Using this strategy allows us to identify the effects of pollution in more recent data, to compare the effects of several criteria pollutants, and to distinguish between the effects of prenatal and post-natal pollution exposure.

A final issue is that this paper (like the others discussed above) examines the effect of outdoor air quality measured using a fixed monitor. Actual personal exposures are affected by ambient air quality, indoor air quality, and the time the individual spends indoors and outdoors. One might expect, for example, that infants spend little time outdoors, so that outdoor air quality might not be relevant.

The research on the relationship between indoor and outdoor air quality has established several results (see Spengler, Samet and McCarthy (2000) for a survey of the literature on indoor air pollution). First, much of what is outdoors comes indoors-estimates of the fraction of indoor fine particles that originated outdoors range from $46 \%$ to $84 \%$ depending on whether the house was air-conditioned and whether windows were left open (Wilson, Mage, and Grant, 2000). The

\footnotetext{
${ }^{5}$ Although Almond, Chay, and Lee (2002) argue that birth weight does not have a causal effect on infant mortality, low birth weight is still widely acknowledged to be the leading indicator of poor health at birth.
} 
rate at which outdoor air circulates through a house depends on the season and the weather, variables we will control for in our analysis.

Second, although the cross-sectional correlation between ambient air quality and personal exposure is low (between .2 and .6 in most studies of PM for e.g.), the time-series correlation is higher. This is because for a given individual, indoor sources of air pollution may be relatively constant and uncorrelated with outdoor air quality. So for a given individual, much of the variation in air quality comes from variation in ambient pollution levels (Wilson, Mage, and Grant, 2000).

\section{Data}

Detailed data on atmospheric pollution comes from the California Environmental Protection Agency's air monitoring stations. These monitors record ambient levels of "criteria pollutants", which are those air pollutants considered most responsible for urban air pollution. Monitors tend to be located in the most densely populated areas of the state, and also in those that are most polluted. The location of monitors may also change over time. Hence, in this analysis, we use only those monitors that existed continuously throughout the period, although using all monitors does not change our results. 6

Following Neidell (2003), we use the monitor data to construct a measure of pollution for each zip code in the state as follows: First, we calculate the centroid of each zip code. We then measure the distance between the EPA monitor and the center of the zip code. Finally, we calculate a weighted average pollution level using all monitors within a 20-mile radius of the zip code's center, using the inverse of the distance to the monitor as the weight. We use this method

\footnotetext{
${ }^{6}$ The data is the California Ambient Air Quality Data from the California Air Resources Board, a department of the California Environmental Protection Agency (available at http://www.arb.ca.gov/aqd/aqded/aqded.htm).
} 
to construct a pollution measure for each zip code and time period. Using this method, we are able to assign a pollution level to zip codes covering about 70 percent of the births in the state. Zip codes that we were not able to assign pollution levels to are overwhelmingly rural. While not every urban zip code has a monitor, of the births included in our sample, $76 \%$ were within 10 miles of a monitor, and we obtain very similar results if we limit our analysis to this subsample, as shown below.

In order to assess the accuracy of our measure, we compare the actual level of pollution at each monitor location with the level of pollution that we would assign using our method (i.e. using the distance weighted average of data from all other monitors less than 20 miles away, if the monitor in question was not there). The correlations between the actual and predicted levels of pollution are remarkably high for $\mathrm{O} 3$ and for NO2 (.92 and .90, respectively). Correlations for PM10 and CO are somewhat lower, but still high (.77 and .78) suggesting that our measure is reasonably accurate. Note that this measurement error means that the estimates reported below will tend to understate the actual effects of pollution somewhat.

Descriptive statistics for the pollution variables are shown in the first panel of Table 1, which also describes the units. 7 Table 1 shows that there is considerable variation in these measures, both between zip codes, and within zip codes over time, over our sample period. For example, the within zip code standard deviation for CO is .777 compared to the between zip code standard deviation of .677 (which can be compared to the mean of 1.975 units.)

The pollutants we examine exhibit different seasonal patterns, as shown in Figure 1. In California, ambient levels of CO, PM10 and NO2 tend to increase in cold weather when they are

\footnotetext{
${ }^{7}$ These measures are highly correlated with measures of short-term spikes in pollutants. For example, the correlation between the maximum 1 hour reading for $\mathrm{CO}$ and the maximum 8 hour average for $\mathrm{CO}$ ranges from .91
} 
trapped by damp cold air. PM10 also spikes in cold weather because it is produced by combustion sources used for heating. In general, levels of CO, PM10, and NO2 are highly correlated which may make it difficult to disentangle their effects. Moreover, NO2 is a major precursor of PM10 in California, which suggests that these two pollutants may be particularly highly correlated. We will examine the sensitivity to our estimates to excluding NO2 below. On the other hand, ozone forms at a higher rate in heat and sunlight. Thus ozone emissions spike during the summer. As we will show below, the negative correlation of ozone with other pollutants can yield wrong-signed effects in single-pollutant models.

Our models include monthly fixed effects to control for seasonal effects, which removes some of the variation in pollution, but Figure 2 shows that a great deal of within zip code variation remains. Figure 2 plots residual levels of pollution after the zip code dummies, month and year dummies, weather indicators and all of the other variables included in our models have been controlled for. Residuals are normalized by mean pollution levels so that they are expressed in percentage terms. (Weather data come from the Surface Summary of the Day (TD3200) from the National Climatic Data Center available at http://www4.ncdc.noaa.gov/cgi-win/wwcgi.dll?wwAW MP\#MR.) It is very important to establish that there is significant within zip code variation, since mean differences in the level of pollutants between zip codes are not used to identify the effects of pollution in the zip code fixed effects models.

Data on birth weight, gestational age, infant deaths and fetal deaths come from the California Birth Cohort files for 1989 to 2000. These data are abstracted from birth, death, and fetal death certificates. Birth weight is the single most widely used summary measure of infant 
health, and low birth weight (defined as birth weight less than 2500 grams) is a marker for higher rates of infant mortality and other negative outcomes. Most infants who are low birth weight are also premature (defined as gestation less than 37 weeks), so we also look at this outcome. Note, that there is no birth cohort file for 1998, so this year is excluded from our analysis.

The distinction between fetal and infant death is that a child must be born alive in order to be registered as an infant death. In California, a live birth is defined as "the complete expulsion or extraction from its mother of a product of conception... which, after such separation, breathes or shows any other evidence of life...", while a fetal death is a "death prior to complete expulsion or extraction from its mother of a product of conception" (California Code of Regulations, Title 17, sections 915 and 916).

Hence, a premature delivery that ended in a child dying before birth would be classified not as an infant death, but as a fetal death. If pollution has an effect on fetal deaths, then examining only the population of live births may yield biased estimates of its true effects. For example, if pollution causes a fetus that would have been born alive, but low birth weight to be stillborn, then it could even appear that pollution increased birth weight.

Since fetal death certificates give birth weight and gestation, we combined live births and fetal deaths in order to create a sample of pregnancies lasting at least 26 weeks for our examination of birth weight, gestation, and fetal death. Examination of the effects of pollution on this sample will give us estimates of the effects of pollution on birth outcomes that are not biased by fetal selection that occurs after 26 weeks. While pollution might also cause fetal deaths before 26 weeks, the data does not support an analysis of this issue.

Descriptive statistics for these variables are also shown in Table 1. The infant mortality rate here is the number of infants who die in a particular quarter divided by the number of infants 
less than one year old; hence to compare to published figures one would multiply this number by four. The estimates indicate that over the sample period, about 6.56 children per 1,000 died in their first year. Table 1 shows that about nine percent of pregnancies lasting at least 26 weeks have gestation less than 37 weeks, while about 5 percent of pregnancies result in a low birth weight delivery. Finally, the rate of fetal death is similar to the infant mortality rate.

In addition to the infant health measures, Birth Cohort File variables relevant for our analysis include the date of birth, mother's age, race and ethnicity, education, marital status, and the 5-digit zip code of maternal residence, as well as information about use of prenatal care and whether the birth was covered by public health insurance. The rapid increase in the fraction of births covered by Medicaid is a potential confounding factor when examining birth outcomes because there is evidence that Medicaid coverage changed the way that at risk infants were treated (c.f. Currie and Gruber, 1996), so it is fortunate that we can control for Medicaid coverage of the birth directly. Unfortunately, it is not possible to control for maternal smoking, since this information is not included on California's birth certificate.

The third panel of Table 1 shows trends in pollution levels over the sample period. All four pollutants show considerable declines. The fourth panel of Table 1 shows that although the infant mortality rate fell sharply over a relatively short time, trends in low birth weight and gestation were much flatter. This part of the table suggests then, that declines in mortality were largely due to events occurring after the birth, rather than to improvements in prenatal health. Finally, the last panel of Table 1 lists the federal standards for the pollutants we examine. A comparison of the first and last panels of the tables suggests that current pollution levels in California are well under these standards. 
Table 2 shows mean outcomes and pollution levels as well as means of various control variables by zip code pollution level. In order to rank zip code-years by pollution level, we first standardized all of the pollution measures using a "z-score" and then took the average of the four measures. While this is a rough way to rank areas, Table 2 indicates that it is informative--there are sharp differences in ambient pollution levels between the most polluted and the least polluted areas of the state. For example, the CO measure is more than twice as high in the most polluted areas compared to the least polluted ones.

These gradients correspond to gradients in birth outcomes: The most polluted areas have uniformly worse outcomes than the least polluted ones. This association could be due to the fact that pollution levels are highly correlated with socioeconomic characteristics that are themselves predictive of poorer birth outcomes. For example, Table 2 shows that more polluted areas tend to have more mothers who are black and unmarried, and have fewer mothers who are college educated. In what follows, we will control for these important observable differences between locations, as well as for unobservable zip code-level characteristics by including zip code-level fixed effects.

Finally, the bottom portion of Table 2 shows differences in zip code-level pollution exposures by individual race and maternal education. The table shows that although high pollution zip codes have a higher fraction black than low pollution zip codes, the average black mother is exposed to similar levels of air pollution as the average white mother. The differences by education are somewhat greater, but are surprisingly small given the large differences between zip codes. The final panel of Table 2 gives the numbers of births in the various categories, which will be used to calculate the number of deaths averted due to pollution reduction below. 


\section{Methods}

We begin by estimating models of the effects of prenatal pollution exposure on the probability of low birth weight, short gestation, and fetal death using a 10 percent random sample of all pregnancies that lasted at least 26 weeks (regardless of whether or not the pregnancy ended in a live birth). These models have the form:

$$
P_{i z}=w_{i z} \gamma+p_{z 1} \eta_{1}+p_{z 2} \eta_{2}+\varphi_{z}+\Gamma_{t}+Y_{t}
$$

where $P_{i z}$ is defined as the probability of low birth weight or short gestation; the $w_{i z}$ are timeinvariant covariates measured at the individual level, such as the mother's demographic and background characteristics; the vector $p_{z l}$ measures prenatal pollution exposure (measured at either the last month before birth, the last trimester before birth, the first month of the pregnancy, or the first trimester of the pregnancy); $p_{z 2}$ is a vector of weather variables, defined in a corresponding fashion; $\varphi_{z}$ is a zip code specific fixed effect; $\Gamma_{t}$ is a vector of month dummies which allows for seasonal effects, and $Y_{t}$ is a vector of year dummies that allows for state-wide trends in these outcomes. In this model, the main coefficient of interest is $\eta_{1}$, the effect of prenatal pollution exposure on the probability of a negative outcome.

Having used model (1) to analyze the effects of prenatal pollution exposures, we go on to analyze the effects of post-natal exposures on the probability of infant mortality. These models control for birth weight and gestation as a means of controlling for the effect of pollution before the birth, in order to isolate the effect of exposure after the birth.

The probability of death $P_{i z t}$ is specified as:

$$
P_{i z t}=\alpha(t)+w_{i z} \gamma+h_{i z} \pi+x_{z t 1} \beta_{1}+x_{z t 2} \beta_{2}+\varphi_{z}+\Gamma_{t}+Y_{t}
$$

where $\alpha(t)$ is a measure of duration dependence and is specified as a linear spline in the weeks since the child's birth, with breaks after 1, 2, 4, 8, 12, 20, and 32 weeks. These break points 
reflect the fact that death is much more common in the first weeks than thereafter. The $w_{i z}$ are defined as above; the $h_{i z}$ are time-invariant measures of the infants health at the time of the birth, including indicators for low birth weight and short gestation; the $x_{z t l}$ are time-varying measures of pollution exposure, the $x_{z t 2}$ are weather indicators; and the $\varphi_{z}, \Gamma_{t}$, and $Y_{t}$ are defined as in (1). In this model, any effect of prenatal exposures is assumed to be captured via the effects on birth weight and gestation, which are controlled. The main coefficient of interest is $\beta_{1}$, the effect of post-natal pollution exposure on the probability of death.

This model can be thought of as a flexible, discrete-time, hazard model that allows for time-varying covariates, non-parametric duration dependence, and zip code-level fixed effects. The model imposes little "structure" on the pattern of coefficients, allowing the data to "speak for itself", a consideration that is particularly important given the lack of guidance in the literature regarding mechanisms and functional form. Allison (1982) shows that estimates from models of this type converge to those obtained from continuous time models, as discussed further in the appendix. (Note that we have also estimated models using $f\left(P_{i z t}\right)$ as the dependent variable, where $f$ is the logit transformation-the results were very similar).

In order to implement this estimation strategy, we treat an individual who lived for $n$ weeks as if they contributed n person-week observations to the sample. The dependent variable is coded as 1 in the period the infant dies, and 0 in all other periods. Each time-invariant covariate is repeated for every period, while the time-varying covariates are updated each period. $P_{i z t}$ is then regressed on the covariates specified in (2) by ordinary least squares.

This procedure yields a very large number of observations. Most infants survive all 52 weeks of their first year, yielding a sample of 250 million weekly observations. Hence, we employ case-control sampling to reduce the number of observations. First, we keep all 
individuals who died (the cases) in the week that they died. Then, in order to select controls, we choose randomly among all the observations on children who lived for at least as many periods as the index child, and who were in the same zip code, and we take the control child's observation for that week. That is, if a child died in week 3, the controls would be chosen from observations on all children who lived at least 3 weeks regardless of whether they later died. For each zip code-week, we randomly chose five times as many non-deaths as deaths (we show below that results using 15 times as many non-deaths are very similar). This method greatly reduces computational burden while yielding unbiased estimates of the effects of pollution on the probability of death (Mantel (1973), Prentice and Breslow (1978), Lubin and Gail (1984)).8

As discussed above, we chose a week as the unit of time in our base specification. A potential problem with choosing such a small interval is that children who die from exposure to high amounts of pollution in week $t$, might have died at $t+1$ in any case. This problem of mortality displacement is sometimes referred to as "harvesting" (Schwartz (2001)). If harvesting is an important phenomenon, then estimates based on weekly pollution measures will tend to overstate the loss of life caused by pollution. For example, the actual loss of life might be only one week, rather than average life expectancy at birth. Moreover, models estimated using weekly pollution focus on the short-term effects of pollution exposure.

On the other hand, a problem with models using longer time units, such as months, is that the measure of pollution is imprecisely assigned. For example, if we use the month as the

\footnotetext{
${ }^{8}$ In contrast, suppose we took all children who died, and selected a control group by sampling all children who survived their first year. At any point in time during the year, we would have a sample that excluded infants who were at risk of death, but survived only to die later. We reproduce Mantel's discussion of why retaining individuals on the basis of their outcomes only adds a constant to the log odds ratio in the Appendix. Since we begin with the entire universe of births and can choose the sample to analyze, we have followed the case control literature that specifies the correct way to choose an analysis sample rather than the economics literature on "choice-based sampling" which suggests estimation methods to deal with samples that have been chosen non-randomly (c.f.
} 
time unit, children who die in their first week of life are incorrectly assigned average pollution levels for all of the days in the month.

Thus, using longer time periods involves more measurement error, which could bias coefficients downwards, especially if it is the acute effects of exposure that matter. Still, it is important to note that PM10, in particular, is only measured once every six days, and is quite variable, so that readings over a few weeks might actually give a more accurate picture of the amount of pollution a child was exposed to. In order to deal with these problems, we will compare estimates from models using weeks to estimates from models using months as the time unit, and we also try augmenting our weekly model by including average cumulative weekly exposures.

Note that since weather is a key determinant of pollution levels, but could also have independent effects on infant health, we include controls for maximum temperatures and average precipitation in the vector $x_{z t 2}$. These controls are specified to be in the same time units as the pollutants-for example, if both pollution in the weeks after birth and pollution in the last trimester are included in the model, then variables measuring the weather during these periods are also included. To the extent that weather affects pollution without having an independent effect on infant health, including the weather variables will reduce the amount of legitimate variation in our pollution measures, and attenuate the estimated effects (Samet et al., 1997). However, as shown below, we find that the exclusion of the weather variables has little effect on our estimates.

Manski and Lerman, 1977; Imbens, 1992). 


\section{Results}

a) Effects of Prenatal Exposures

Table 3 shows estimates of model (1), where the dependent variable is the probability of short gestation. For convenience, the coefficients and standard errors on the pollutants and on the weather variables are multiplied by 1000 . For comparison with previous work, we first estimate cross sectional models for each pollutant separately. The "single pollutant" models without zip code fixed effects shown in columns (1) through (4), indicate that exposure to PM10, NO2, and Ozone in the month before birth all increase the probability of short gestation. Column (5) shows that if we include all four pollutants, only PM10 and Ozone have significant effects. The estimated effects are slightly larger if NO2 is excluded from the model, as shown in column (6).

However, as discussed above, the pollution measures may be capturing other characteristics of zip codes. Columns (7) through (12) of Table 3 show the same models estimated using zip code fixed effects. The estimated effects of pollution on the probability of short gestation disappear, suggesting that it is very important to control for omitted variables.

Table 3 also displays the other covariates included in our models. These variables have largely the expected signs and are not much affected by the inclusion of the fixed effects. For example, infants born to black, unmarried, less educated mothers are more likely to suffer from short gestation than other infants, as are infants of high parity.

The first two panels of Table 4 present estimates from similar models of low birth weight, and the probability of fetal death. Only the estimated effects of pollution are shown; the coefficients on the other covariates are supressed in order to save space. Even in the cross section, we find little consistent evidence that pollution affects these outcomes once the 
observable characteristics of mothers are controlled. In the fixed effects models $\mathrm{CO}$ is significant when all four pollutants are included in the model (see column 11). However, this may be an artifact of collinearity since the significant effect disappears when NO2 is omitted from the model (see column 12).

The literature gives little guidance about when in pregnancy pollution is likely to be most harmful. Therefore, we have estimated models similar to those shown in Tables 3 and 4 using pollution measured in the first month of pregnancy, the last trimester of pregnancy, and the first trimester of pregnancy. The only notable result is displayed in the third panel of Table 4, which shows that when we use the last trimester rather than the last month of pregnancy, the crosssectional estimates of the effects of pollution on the probability of short gestation are larger than those shown in Table 3. However, when zip code fixed effects are included in the model, none of the effects are statistically significant. Similarly, we found little evidence that pollution in the first month or first trimester of pregnancy was harmful, at least at the levels in our study.

It is possible however, that the effects of pollution are non-linear; that is, they are harmful above some threshold level. It is also possible that pollution has a more negative effect on more vulnerable infants. Table 5 shows the results of several attempts to test this hypothesis by including interactions with a) whether the mother lives in one of the "high pollution" zip codes identified in Table 2; b) whether the mother is black; and c) whether the mother has less than a high school education. In the fixed effects models, we find little evidence of non-linear or differential effects on low birth weight or short gestation. However, the third panel of Table 5 shows that $\mathrm{CO}$ appears to have a stronger effect on the probability of fetal death in high pollution zip codes (although the total effect for these infants is still either zero or negative), and among the children of mothers with less than a high school education. 


\section{b) Effects of Pollution on Infant Mortality}

Table 6 shows estimates of model (2). A comparison of the cross-sectional and fixed effects estimates shows that the estimates are quite robust to the inclusion of zip code fixed effects, in contrast to the models of prenatal exposures discussed above. The single-pollutant models suggest that $\mathrm{CO}, \mathrm{PM} 10$, and $\mathrm{NO} 2$ exposures all increase the probability of death, while ozone has a counter-intuitive negative effect. However, when all four pollutants (or when CO, PM10, and ozone are included) only CO has a significant effect.

The figures in bold are the implied number of deaths associated with a one unit increase in the pollutant in question, per 100,000 births. Given the 4,720,190 births in areas where pollution could be assigned over our sample period, the estimate of 13.864 in the last column of Table 6 suggests that the one unit decline in $\mathrm{CO}$ that took place over the sample period saved 654 infant lives. (Note that we do not consider possible lives saved in areas without pollution monitors. If these areas did not have monitors because they had little pollution and/or were sparely populated, then reductions in pollution could be expected to have relatively little effect).

Table 7 shows that the estimated effect of $\mathrm{CO}$ is extremely robust to many changes in specification. Except for columns 5 and 6, all of the models included zip code fixed effects. The coefficients on the other covariates are excluded from the table in order to conserve space.

Columns 1 and 2 of Table 7 use a sample in which 15 times as many non-deaths as deaths were chosen (rather than 5 times). While the standard errors are smaller, as one would expect, the effect sizes are very similar to those in Table 6 . Columns 3 and 4 show the effect of excluding temperature and precipitation, and demonstrate that this has little effect. Columns 5 and 6 show estimates from models that include a fixed effect for each zip code and year. While this specification controls for everything shared by mothers within a particular zip code and year, 
it is not our preferred specification, because some zip code-year cells have no deaths.

Nevertheless, it is reassuring to find that the inclusion of these additional fixed effects has little effect on the estimates.

Columns 7 and 8 show estimates from models that exclude deaths (and controls) from the first week of life. Our rationale for this specification check is that infants who are very sick may never leave the hospital, and the quality of the air they are exposed to may be strictly controlled (if they are in an incubator, for example). Once again, this change has relatively little effect on our estimates.

Columns 9 and 10 show estimates from models that use data from monitors within a 10 mile radius of each zip code centroid. The sample size is smaller, given that those who live between 10 and 20 miles away from a monitor are now excluded. However, the estimates are similar to those in Table 6.

Finally, columns 11 and 12 show estimates from models where the unit of time is the calendar month, rather than the week. As discussed above, the use of a broader time unit could attenuate the estimated effects by introducing more measurement error. Alternatively, it may increase the estimated effects for pollutants like PM10 that are measured irregularly, or that are thought to have cumulative impacts. Column 12 suggests that the estimated effect of $\mathrm{CO}$ is again robust to this change in specification, which indicates that the estimated effect is unlikely to be driven by "harvesting". However, as hypothesized, the estimated effect of PM10 is increased by moving to a longer time interval. The point estimate implies that the 15.9 unit decline in PM10 that took place over our sample period reduced the number of deaths by 415 over the sample period. 
Table 8 shows estimates from a model intended to get at possible cumulative effects of pollution in an alternative way. In addition to the weekly measures of pollution exposure, the models shown in Table 8 also include the average weekly exposure over the child's life. This modification has little effect on the estimated coefficient on CO. However, in column 5, the cumulative effect of NO2 is large and statistically significant, while column 6 shows that the cumulative effect of PM10 is significant when NO2 is omitted. Thus, the last two rows of Table 7 and Table 8 suggest that PM10 (and possibly its precursor NO2) have cumulative effects on infant health which increase the probability of mortality. Still, the estimated effect of PM10 in Table 8 is considerably smaller than in Table 7, suggesting that exposure in the last few weeks may matter more than cumulative exposure over the infant's entire lifetime.

We have also investigated possible non-linearities in the effects of pollution on infant mortality, as well as the possibility that pollution has different effects on different groups by estimating models similar to those shown in Table 5. None of the interaction terms in these models were statistically significant. Hence, we find little evidence of a non-linear effect of pollution on infant mortality (at least over the range of pollution measured in our data), and conclude that the same exposure to pollution will have the same effect on mortality risk regardless of race or maternal education.

The estimates in Table 2 suggested that there were small differences in the average pollution levels experienced by children of mothers with and without a high school education. We calculate that the mean difference of .229 units in $\mathrm{CO}$ exposure could be responsible for an extra 51.82 deaths in the less educated group relative to the more educated group over the sample period, while the 3.077 unit difference in PM10 exposure could have accounted for 27.82 
extra deaths in the less educated group. Still, this is a relatively small fraction of the overall difference $(4,885)$ in the number of deaths between the two groups.

To summarize, CO and PM10 appear to have the most significant effects on infant mortality. The estimated effect of $\mathrm{CO}$ is remarkably robust to many changes in specification, and implies that reduction in $\mathrm{CO}$ over our sample period saved approximately 654 lives in California. The coefficient on PM10 is more sensitive to specification, but the models using monthly measures suggest that the decline in PM10 saved 415 lives over the same period.

The estimated effect of PM10 is smaller than the Chay and Greenstone estimates of the effects of TSPs. The single pollutant model for PM10 using the monthly measure (which is not shown) implies that each one unit reduction led to a decline of 1.17 deaths per 100,000 . However, it must be kept in mind that the estimates are not directly comparable, given that TSPs are a broader measure than PM10 (while roughly half of TSPs are less than 10 microns in diameter, smaller particles are thought to have the worst effects), and that Chay and Greenstone use more aggregate data. The effect of PM10 in aggregate data is investigated further in the next section.

\section{c) Estimated Effects in More Aggregate Data}

Several previous studies have used aggregate rather than individual-level data and it is of interest to compare our results with theirs. Hence, we have aggregated our data to the zip codequarter level and estimated models similar to (1) and (2). All of the models in Table 9 control for zip code fixed effects. Note that in the infant mortality regressions, we now control only for pollution in the quarter of birth. These models are shown in Table 9. The sample size for the infant mortality regressions is slightly smaller than for the birth outcome regressions, because for 1989 , the rate can only be calculated for the last quarter of the year. In order to compare the 
effect sizes to those indicated in bold in Tables 6 and 7, it is necessary to multiply coefficients and standard errors by 100 to give the effect per 100,000 live births.

The first panel of Table 9 shows that in the aggregate-level data, only PM10 has a statistically significant effect in the multi-pollutant models--there is no statistically significant effect of $\mathrm{CO}$. This observation suggests that estimates based on aggregate data will significantly under-estimate the effects of $\mathrm{CO}$, perhaps because acute exposures matter. On the other hand, the point estimate of .004 on PM10 in column (6) indicates that there was a decline of .4 deaths per 100,000 per unit of PM10 reduction per quarter, or a reduction of 1.6 deaths per 100,000 annually, which is larger than the estimate of .554 per 100,000 implied by the comparable Table 7 estimate. Hence, it does appear that the estimated effects of PM10 are larger in more aggregate data.

The rest of the Table shows that once again, we find little consistent effect of pollution on the incidence of prematurity or fetal death in the fixed effects models. Panel 2 indicates however, that the coefficient on CO is significant in the multi-pollutant model for low birth weight, and very large. However, the fact that $\mathrm{CO}$ is not significant in the single-pollutant model suggests that the finding in the multi-pollutant model may be due to collinearity between the pollution measures.

\section{Discussion and Conclusions}

Environmental policy continues to be contentious. For example, the EPA has responded to the threat posed by increased diesel emissions by proposing new rules that would require refiners to phase in cleaner diesel fuel between 2006 and 2010, but the American Petroleum Institute and the National Petro-chemical and Refiners Association have filed suit in an effort to 
block implementation of these standards (Stafford, 2001).9 Similarly, there is controversy over the Bush administration's recent "Clear Skies" initiative, which would eliminate the requirement that older power plants upgrade their pollution controls when they upgrade or modernize their equipment and replace them with "cap and trade" provisions. Critics contend that the plan would not regulate $\mathrm{CO}$ production, provides weaker caps than alternative legislation introduced in the Senate, and will not necessarily reduce pollution in the most polluted areas, an important consideration if the effects of pollution are non-linear (Environmental Defense, 2003).

In order to begin to evaluate the costs and benefits of such policies, it is necessary to understand how changes from current, historically low levels of air pollution are likely to affect health, and which pollutants have the greatest health effects. This paper examines the effects of air pollution on infant health, using recent data from California. Our models are identified using within zip code variation in pollution, so that we are able to control for unobservable fixed characteristics of zip codes as well as for a detailed group of observable time-varying characteristics.

Controlling for detailed characteristics of individuals including zip code of residence causes us to overturn some of the findings in the cross-sectional epidemiological literature concerning prenatal pollution exposures. For example, we find little average effect of prenatal pollution exposure on the probability of low birth weight, short gestation, or fetal death once zip code fixed effects are included in individual-level models, although there is some evidence that people in high pollution areas, and children whose mothers have less than a high school education, may be more subject to fetal death induced by pollution.

\footnotetext{
${ }^{9}$ Due to increased driving, trucks burning diesel emitted more nitrogen oxides and particles in 1997, than they did in 1970 when the Clean Air Act was passed.
} 
In "single pollutant" models that include fixed effects, we find that CO, PM10, and $\mathrm{NO} 2$ all increase infant mortality. Our results for $\mathrm{CO}$ also hold in "multi-pollutant" models and are extremely robust to many changes in specification. The estimated effects of PM10 and NO2 (an important precursor) are more sensitive to specification, and show some signs of collinearity. However, our preferred estimates imply that reductions in CO and PM10 over the time interval we study saved over 1,000 infant lives in California alone. These findings are clearly relevant to policy debates over automobile emissions and the Clear Skies Initiative, for example.

A complete evaluation of the costs and benefits of improvements in air quality is far beyond the scope of this paper (see for example, Greenstone (2002) who calculates the cost of the 1970 and 1977 Clean Air Act Amendments, or Sieg et al. (2000) who examine willingness to pay for air quality improvements in the context of a general equilibrium model of housing prices). Note however that there are several reasons why the health benefit that we measure here might not be capitalized into housing prices. First, the effects of pollution on infant health are not well known-that is a starting point for this research. Second, CO is a colorless, odorless gas and people may not be willing to pay for reductions in pollution that they do not observe. Third, to the extent that parents place a lower value on infant health relative to other goods than infants would, the value of their health will not be fully captured by the parents' willingness to pay for pollution reduction.

What is the value then, of improvements in infant health due to reductions in pollution? If we value a life at a very conservative $\$ 1.6$ million, then the estimated reduction in infant deaths due to reduced air pollution in California over the 1990s would be valued at $\$ 1.7$ 
billion.10 If we use the EPA(1999) value of $\$ 4.8$ million, the benefit would grow to $\$ 5.1$ billion. These estimates ignore other benefits of pollution reduction, such as improvements in health which are not at the life/death margin, and so are lower-bound estimates of the benefits to infants. But they may still provide a useful benchmark for assessing the benefits of further reductions in air pollution in terms of infant health.

${ }^{10}$ Chay and Greenstone (2001a) use this $\$ 1.6$ million value. However, Viscusi (1993) suggested that the value of a life was between $\$ 3.5$ and $\$ 8.5$ million, and U.S. EPA (1999) valued infant lives lost due to lead at $\$ 4.8$ million, the same value that they used for adult lives. 


\section{References}

Alderman, Beth, Anna Baron, and David Savitz. "Maternal Exposure to Neighborhood Carbon Monoxide and Risk of Low Infant Birth Weight," Public Health Reports, 102 \#4, July-August 1987, 410-414.

Allison, Paul, "Discrete-Time Methods for the Analysis of Event Histories," Sociological Methodology, 13, 61-98, 1982.

Almond, Douglas, Kenneth Chay and David Lee. "Does Low Birth Weight Matter? Evidence from the U.S. Population of Twin Births", Xerox, Dept. of Economics, Berkeley (August 2002)

Bobak, M. "Outdoor Air Pollution, Low Birth weight, and Prematurity", Environmental Health Perspectives, 108, 2000, 173-176.

Chay, Kenneth and Michael Greenstone. "The Impact of Air Pollution on Infant Mortality: Evidence from Geographic Variation in Pollution Shocks Induced by a Recession", forthcoming, Quarterly Journal of Economics.

Chay, Kenneth and Michael Greenstone. "Air Quality, Infant Mortality, and the Clean Air Act of 1970", xerox, Dept. of Economics, Berkeley, August 2001.

Currie, Janet and Jonathan Gruber. "Saving Babies: The Efficacy and Cost of Recent Expansions of Medicaid Eligibility for Pregnant Women," The Journal of Political Economy, December, 1996

Dejmek, J. S.G. Selevan, I. Solansky, RJ. Sram. "Fetal Growth and Maternal Exposure to Particulate Matter During Pregnancy", Environmental Health Perspectives, 107, 1999, 475-480.

Doggett, Tom. "White House, EPA Clash on Lower Vehicle Emissions", Reuters wire service, October 17, 2002.

Environmental Defense. "President's Clear Skies Initiative Won't Clean Pollution Without Changes", New Release, Jan 28, 2003, www.environmentaldefense.org/pressrelease.cfm?ContentID $=2629$.

Friedman, Michael, Kenneth Powell, Lori Hutwagner, LeRoy Graham, W. Gerald Teague. "Impact of Changes in Transportation and Commuting Behaviors During the 1996 Summer Olympic Games in Atlanta on Air Quality and Childhood Asthma," Journal of the American Medical Association, 285 \#7, Feb. 21, 2001, 897-905.

Garvey, D.J. and L.D. Longo. "Chronic Low Level Maternal Carbon Monoxide Exposure and Fetal Growth and Development" Biology and Reproduction, 19, 8-114, 1978. 
Greenstone, Michael. "The Impacts of Environmental Regulations on Industrial Activity: Evidence from the 1970 and 1977 Clean Air Act Amendments and the Census of Manufactures", Journal of Political Economy, CX, 2002.

Hales, Simon, Clare Salmond, G. Ian Town, Tord Kjellstrom, Alistair Woodward. "Daily Mortality in Relation to Weather and Air Pollution in Christchurch, New Zealand", Australian and New Zealand Journal of Public Health, 24:1, 1999, 89-91.

Imbens, Guido. "An Efficient Method of Moments Estimator for Discrete Choice Models with Choice-Based Sampling," Econometrica 60 (1992): 1187-1214.

Lipfert, F. W., J. Zhang, and R.E. Wyzga. "Infant Mortality and Air Pollution: A Comprehensive Analysis of U.S. Data for 1990", Journal of the Air Waste Management Association, 50(8), August 2000, 1350-1566.

Logan, W.P.D. and M.D. Glasg. "Mortality in London Fog Incident, 1952", Lancet 1:336-338, 1953.

Loomis, Dana, Margarita Castillejos, Diane Gold, William McDonnell, Victor Hugo BorjaAburto. "Air Pollution and Infant Mortality in Mexico City," Epidemiology Resources, 10 \#2, 1999, 118-123.

Longo, L.D. "The Biological Effects of Carbon Monoxide on the Pregnant Woman, Fetus and Newborn Infant", American Journal of Obstetrics and Gynecology, 129, 690103, 1987.

Lubin, Jay and Mitchell Gail, "Biased selection of controls for case-control analyses of cohort studies" Biometrics 40 (1), 63-75, 1984.

Lui, Shiliang, Daniel Krewski, Yuanli Shi, Yue Chen, and Richard Burnett. "Association between Gaseous Ambient Air Pollutants and Adverse Pregnancy Outcomes in Vancouver Canada," Environmental Health Perspectives, 111 \#14, November 2003, 1773-1778.

Maisonet, Mildred, Timothy Bush, Adolfo Correa, and Jouni Jaakkola. "Relation Between Ambient Air Pollution and Low Birth Weight in the Northeastern United States," Environmental Health Perspectives, 109 \#3, June 2001, 351-356.

Manski, Charles and Steven Lerman. "The Estimation of Choice Probabilities from Choice Based Samples," Econometrica, 45 \#8, Nov. 1977, 1977-1988.

Mantel, Nathan, "Synthetic retrospective studies and related topics," Biometrics 29(3), 479-486, 1973.

Neidell, Matthew. "Air Pollution, Health, and Socio-Economic Status: The Effect of Outdoor Air Quality on Childhood Asthma," CISES Working Paper \#11, October 2003.

Pereira, Luiz, Dana Loomis, Gleice Conceicao, Alfesio Braga, Rosangela Arcas, Humberto 
Kishi, Julio Singer, Gyorgy Bohm, and Paulo Saldiva. "Association Between Air Pollution and Intrauterine Mortality in Sao Paulo Brazil," Environmental Health Perspectives, 106 \#6, June 1998, 325-329.

Pope, C. Arden III. "Respiratory Disease Associated with Community Air Pollution and a Steell Mill, Utah Valley," American Journal of Public Health, 79, 1989, 623-628.

Pope, C. Arden, J. Schwartz, and Michael Ransom. "Daily Mortality and PM10 Pollution in Utah Valley," Archives of Environmental Health, 47, 1992, 211-216.

Prentice, R.L., and N.E. Breslow, "Retrospective studies and failure time models" Biometrika, 65(1), 153-158, 1978.

Ransom, Michael, C. Arden Pope. "Elementary School Absences and PM10 Pollution in Utah Valley," Environmental Research, 58, 1992, 204-219.

Ritz, Beate, and Fei Yu. "The Effects of Ambient Carbon Monoxide on Low Birth Weight Among Children Born in Southern California Between 1989 and 1993", Environmental Health Perspectives, 107, 1999, 17-25.

Ritz, Beate, Fei Yu, Guadalupe Chapa and Scott Fruin. "Effect of Air Pollution on Preterm Birth Among Children Born in Southern California Between 1989 and 1993", Epidemiology, 11 \#5, Sept. 2000, 502-511.

Samet, Jonathan, Scott Zeger, Julia Kelsall, Jing Xu and Laurence Kalstein. "Does Weather Confound or Modify the Association of Particulate Air Pollution with Mortality?" Environmental Research Section A, LXXVII, 1997, 9-19.

Schwartz, Joel, "Harvesting and long term exposure effects in the relation between air pollution and mortality," American Journal of Epidemiology, 151(5), 440-448, 2000.

Seaton, Anthony et al. "Particulate Air Pollution and Acute Health Effects," The Lancet, v354, Jan. 21, 1995, 176-178.

Seig, Holger, V. Kerry Smith, H. Spencer Banzhaf, and Randy Walsh. "Estimating the General Equilibrium Benefits of Large Policy Changes: The Clean Air Act Revisited”, NBER Working Paper \#7744, June 2000.

Spengler, John, Samet, Jonathan and McCarthy, J.F. Indoor Air Quality Handbook (New York, NY:McGraw_hill Book Co.) 2000.

Stafford, Robert T. "An Uphill Drive”, Washington D.C.: Clean Air Trust, 2001.

U.S. Environmental Protection Agency. The Benefits and Costs of the

Clean Air Act, 1990-2010. Report to the U.S. Congress, November 1999. 
U.S. Environmental Protection Agency. "National Ambient Air Quality Standards", Nov. 15 2002, http://www.epa.gov/airs/criteria.html.

U.S. Environmental Protection Agency. "Second Prospective Analytical Plan", May 12, 2003 (Scientific Advisory Board Advisory Council on Clean Air Compliance: Washington D.C.).

U.S. Environmental Protection Agency. "Criteria Pollutants" February 20"th 2003 b, http://www.epa.gov/oar/oaqps/greenbk/o3co.html.

Viscusi, W. Kip. "The Value of Risks to Life and Health" Journal of Economic Literature. 31(4):1912-1946, Dec. 1993.

Wang, X., H. Ding, L. Ryan, X. Xu. "Associations between Air Pollution and Low Birth Weight: A Community-Based Study", Environmental Health Perspectives, 105, 514-520, 1997.

Williams, L. A.M. Spence, and S.C. Tideman. "Implications of the Observed Effect of Air Pollution on Birth Weight", Social Biology, 24, 1977, 1-9.

Wilson, William, David Mage, and Lester Grant. "Estimating Separately Personal Exposure to Ambient and Nonambient Particulate Matter for Epidemiology and Risk Assessment: Why and How", Journal of the Air Waste Management Association, 50, July 2000, 1167-1183.

Woodruff, T.J., J. Grillo, K.C. Schoendorf. "The Relationship Between Selected Causes of Postneonatal Infant Mortality and Particulate Air Pollution in the United States", Environmental Health Perspectives, 105, 1997, 608-612.

Xu, X, H. Ding. X. Wang. :Acute Effects of Total Suspended Particles and Sulfur Dioxides on Preterm Delivery: A Community-Based Cohort Study" Archives of Environmental Health, 50, 1995, 407-415. 


\section{Appendix:}

1. Description of the survival model

The description of this model follows Allison (1982). Define a discrete-time hazard rate:

$P_{i t}=\operatorname{Pr}\left[T_{i}=t \mid T_{i}>t, x_{i t}\right]$

where $P_{i t}$ is the probability of death for individual $i$ in period $t, T$ is the time of occurrence, and $x$ are covariates that affect death.

We can now specify the likelihood function:

$L=\prod_{i=1}^{n}\left[\operatorname{Pr}\left(T_{i}=t\right)\right]^{\partial_{i}}\left[\operatorname{Pr}\left(T_{i}>t\right)\right]^{1-\partial_{i}}$

where $\delta_{i}$ is a dummy variable equal to 1 if the observation is uncensored and 0 otherwise. This is analogous to the continuous time model in that each individual contributes to the likelihood function the hazard rate if uncensored and the survivor function if censored.

Using conditional probabilities, we can restate the hazard and survivor function as:

$$
\begin{aligned}
& \operatorname{Pr}\left(T_{i}=t\right)=P_{i t} \prod_{j=1}^{t-1}\left(1-P_{i j}\right) \\
& \operatorname{Pr}\left(T_{i}>t\right)=\prod_{j=1}^{t}\left(1-P_{i j}\right)
\end{aligned}
$$

After substituting these into the likelihood function, taking logs, and rearranging terms, we are left with:

$\log L=\sum_{i=1}^{n} \sum_{j=1}^{t_{i}} y_{i t} \log \left(\frac{P_{i t}}{1-P_{i t}}\right)+\sum_{i=1}^{n} \sum_{j=1}^{t_{i}} \log \left(1-P_{i t}\right)$

where $y_{i t}=1$ if person $i$ dies in period $t$, and 0 otherwise. This now amounts to the analysis of binary data, and, after specifying the hazard as a function of the covariates, can be estimated by logit model. Alternatively, we can specify the hazard as a linear probability model and estimate it by least squares.

\section{A Note on Case Control Sampling}

Mantel (1973, pages 481-482) provides a simple explanation of case-control sampling. In his analysis, a random proportion $\mathrm{d}_{1}$ of cases, and a random proportion $\mathrm{d}_{2}$ of controls are chosen. It is key that people be chosen from both groups randomly. Intuitively, there is little to be gained by arbitrarily increasing the size of the control group, if the size of the treatment group is fixed. However, it still seems that selecting the individuals to be retained on the basis of their outcome will introduce a bias. Mantel shows however, that only the intercept of the log odds ratio is changed. Specifically, 
"The possible outcomes for individual $i$ with vector $X_{i}$ are:

1) he can develop disease and be in the sample, with probability $d_{1} P\left(Y_{i}=1 \mid X_{i}\right)$;

2) he can develop disease and not be in the sample, with probability $\left(1-d_{1}\right) P\left(Y_{i}=1 \mid X_{i}\right)$;

3) he can remain disease free and be in the sample, with probability $d_{2} P\left(Y_{i}=0 \mid X_{i}\right)$;

4) he can remain disease free and not be in the sample, with probability $\left(1-d_{2}\right) P\left(Y_{i}=0 \mid X_{i}\right)$.

We now make use of the fact that for any truncated multinomial...the probability $P$ ', for a particular observable outcome is its unconditional probability divided by the total of probabilities for observable outcomes. Thus we may write

$P^{\prime}\left(Y_{i}=1 \mid X_{i}\right)=d_{1} P\left(Y_{i}=1 \mid X_{i}\right) /\left[d_{1} P\left(Y_{i}=1 \mid X_{i}\right)+d_{2} P\left(Y_{i}=0 \mid X_{i}\right)\right]$

in consequence of which

$P^{\prime}\left(Y_{i}=1 \mid X_{i}\right) / P^{\prime}\left(Y_{i}=0 \mid X_{i}\right)=d_{1} P\left(Y_{i}=1 \mid X_{i}\right) / d_{2} P\left(Y_{i}=0 \mid X_{i}\right)$

or the log odds

$\log _{\{}\left(P^{\prime}\left(Y_{i}=1 \mid X_{i}\right) / P^{\prime}\left(Y_{i}=0 \mid X_{i}\right)=\log \left(d_{1} / d_{2}\right)+\log \left\{P\left(Y_{i}=1 \mid X_{i}\right) / P\left(Y_{i}=0 \mid X_{i}\right)\right.\right.$

What this implies is that the conditional log odds for being a case has the same dependence on $X_{i}$ as the unconditional log odds; only the intercept is changed." 
Chart 1: Selected Epidemiological Studies of Effects of Pollution on Infant Health

A: Studies of High Pollution Areas

\begin{tabular}{|c|c|c|c|c|c|}
\hline Study & Location & Years & Outcomes & Pollutants & Effects \\
\hline Bobak and Leon (1999) & Czech Republic & $1989-91$ & infant mortality & SO2, TSP, NOX & $\begin{array}{l}\text { Mean lifetime exposure to TSPs increased mortality } \\
\text { due to respiratory causes when all pollutants } \\
\text { entered in model. }\end{array}$ \\
\hline Dejmek et al. (1999) & $\begin{array}{l}\text { Northern Bohemia, } \\
\text { Europe }\end{array}$ & 1994-96 & $\begin{array}{l}\text { Growth } \\
\text { retardation }\end{array}$ & PM10, PM2.5 & $\begin{array}{l}\text { Exposure in } 1 \mathrm{st} \mathrm{month} \text { of pregnancy related to } \\
\text { interuterine growth retardation. }\end{array}$ \\
\hline Luiz et al (1998) & Sao Paulo, Brazil & 1991,92, & fetal death & $\begin{array}{c}\text { index of } \mathrm{CO}, \mathrm{NO} 2 \\
\mathrm{SO} 2, \mathrm{O} 3, \mathrm{PM} 10\end{array}$ & $\begin{array}{l}\text { Index associated with increased risk of fetal death } \\
\text { within } 5 \text { days. }\end{array}$ \\
\hline $\begin{array}{l}\text { Wang, Ding, Ryan, } \\
\text { and Xu (1997) }\end{array}$ & Beijing, China & $1988-91$ & low birth weight & SO2 \& TSP & $\begin{array}{l}\text { Exposure in last trimester increases risk of low } \\
\text { birth weight. }\end{array}$ \\
\hline Xu, Ding, and Wang (1995) & Beijing, China & 1988 & preterm birth & SO2 \& TSP & $\begin{array}{l}\text { 7-day lagged moving average of each pollutant } \\
\text { associated with increased risk of preterm birth. }\end{array}$ \\
\hline
\end{tabular}

B: Studies of the U.S. and Canada

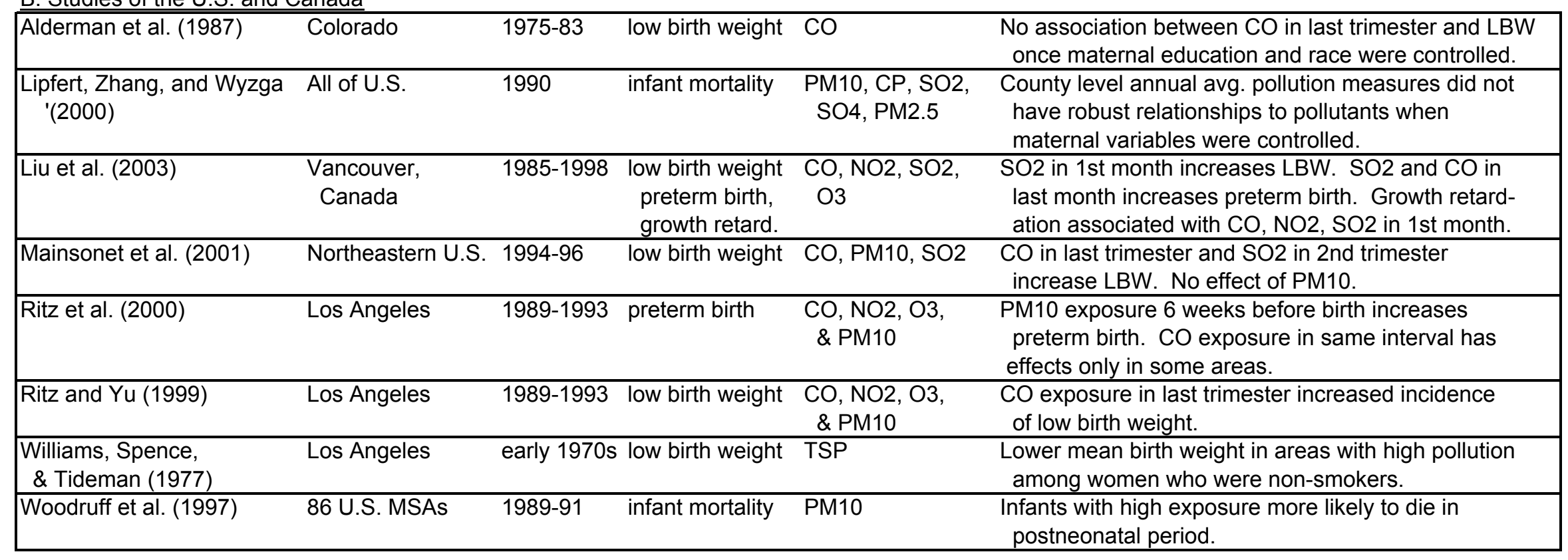




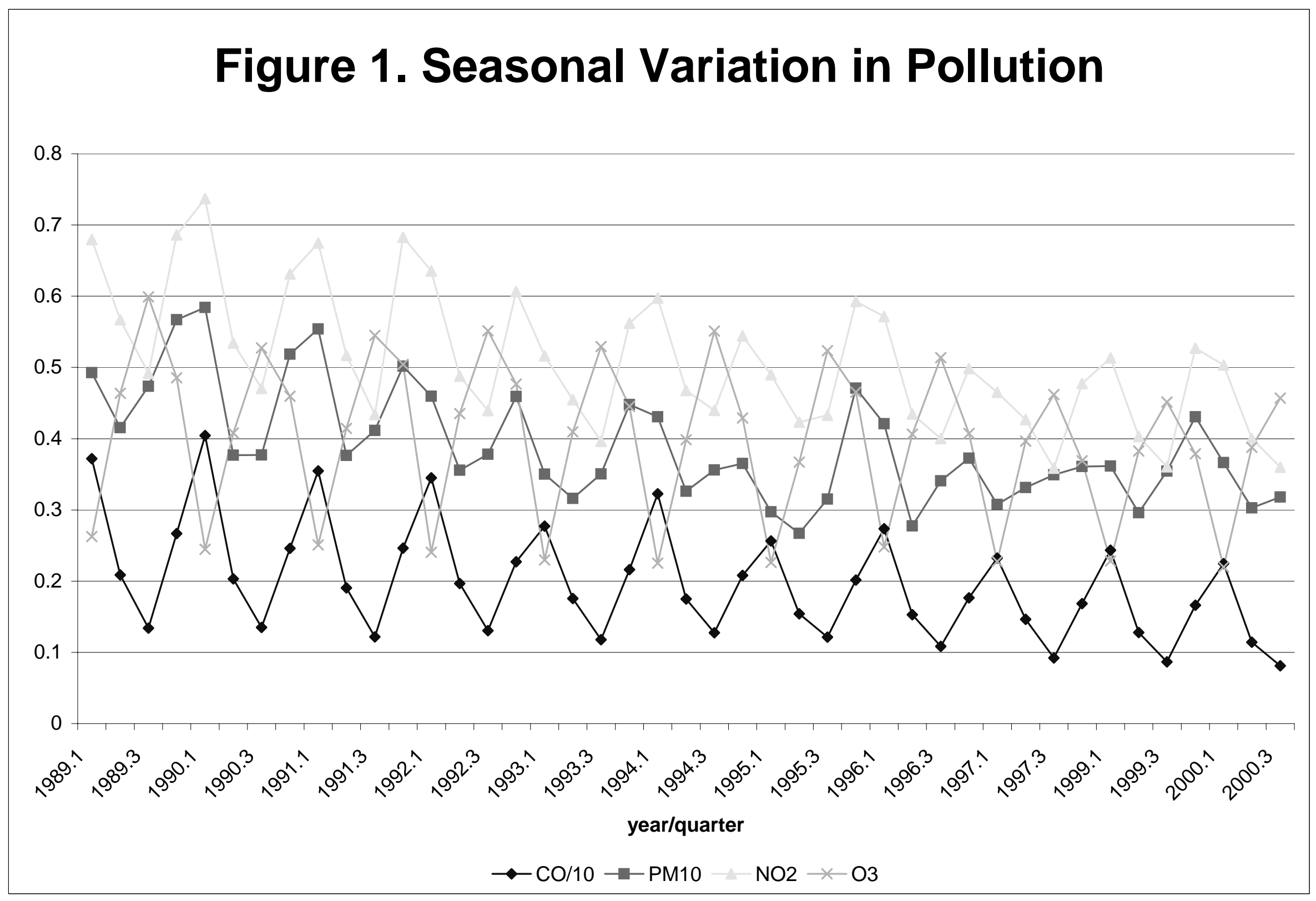




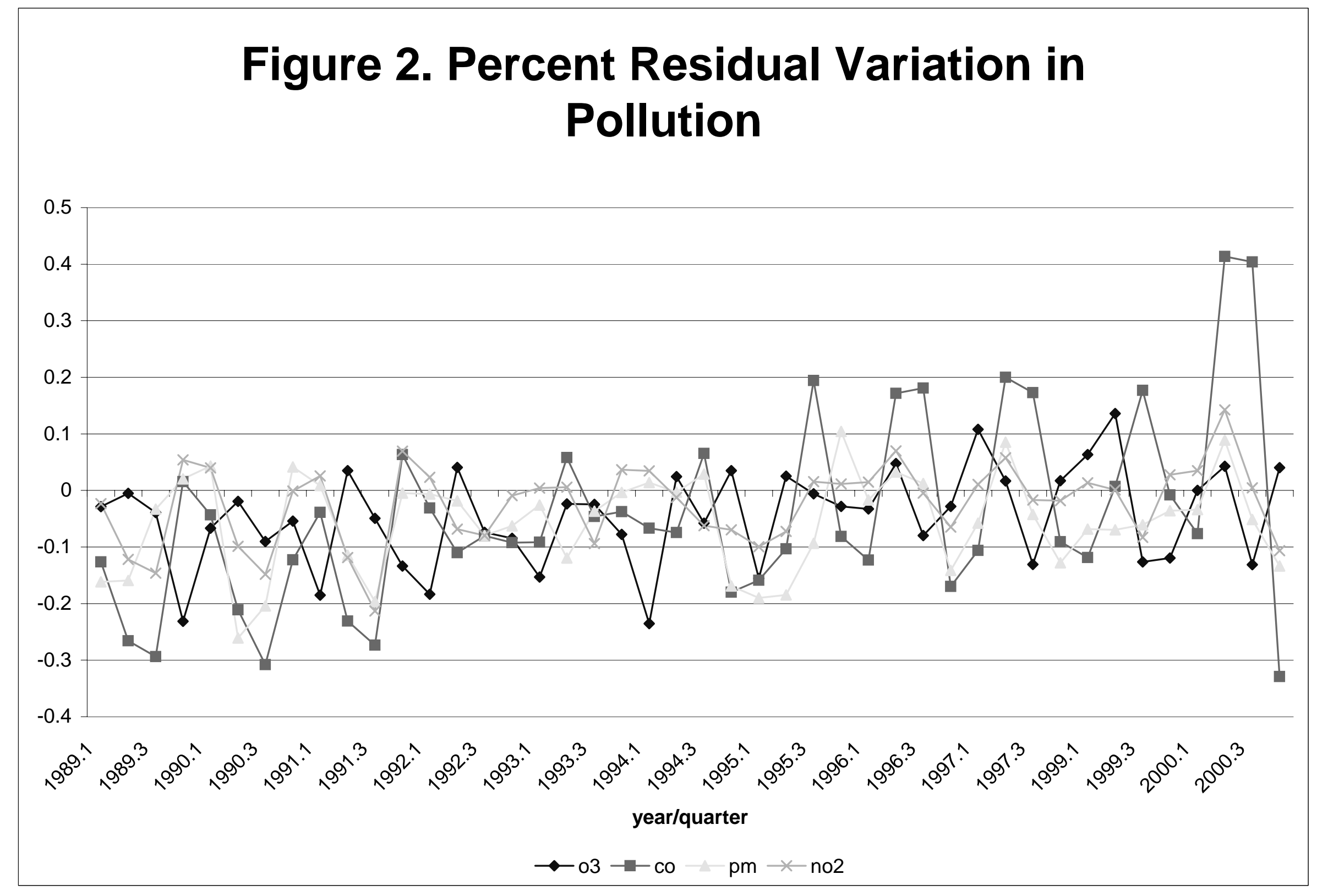


Table 1: Levels and Trends in Pollution and Infant Health

\begin{tabular}{|c|c|c|c|c|}
\hline Variable & Mean & Std. Dev. & $\begin{array}{l}\text { Between zip } \\
\text { std. Dev. }\end{array}$ & $\begin{array}{l}\text { Within zip } \\
\text { std. Dev. }\end{array}$ \\
\hline \multicolumn{5}{|l|}{ Panel 1} \\
\hline$\overline{\mathrm{CO} 8-\mathrm{hr}} \mathrm{ppm}$ & 1.975 & 1.101 & 0.677 & 0.777 \\
\hline PM10 24-hr ug/m3 & 39.125 & 14.165 & 10.833 & 9.244 \\
\hline NO2 1-hr ppb & 50.919 & 18.370 & 15.356 & 9.457 \\
\hline O3 8-hr ppb & 40.424 & 15.929 & 9.937 & 11.802 \\
\hline \multicolumn{5}{|l|}{ Panel 2} \\
\hline Quarterly IMR per 1000 & 1.64 & 1.95 & 4.07 & 11.28 \\
\hline gestation $<37$ per 1,000 & 92.60 & 30.91 & 25.72 & 48.64 \\
\hline low birth weight per 1,000 & 48.80 & 21.59 & 14.94 & 39.08 \\
\hline fetal deaths per 1,000 & 5.86 & 6.58 & 3.38 & 13.64 \\
\hline \multicolumn{5}{|l|}{ Panel 3} \\
\hline year & $\mathrm{CO}$ & PM10 & $\mathrm{NO2}$ & O3 \\
\hline 1989 & 2.409 & 48.817 & 60.340 & 45.993 \\
\hline 1990 & 2.435 & 46.174 & 58.986 & 41.400 \\
\hline 1991 & 2.252 & 45.965 & 57.426 & 43.326 \\
\hline 1992 & 2.243 & 41.339 & 54.208 & 42.709 \\
\hline 1993 & 1.940 & 36.645 & 48.058 & 40.879 \\
\hline 1994 & 2.071 & 36.923 & 51.123 & 40.309 \\
\hline 1995 & 1.822 & 33.728 & 48.383 & 39.799 \\
\hline 1996 & 1.767 & 35.253 & 47.488 & 39.581 \\
\hline 1997 & 1.585 & 33.774 & 43.083 & 36.593 \\
\hline 1999 & 1.544 & 36.098 & 44.936 & 36.259 \\
\hline 2000 & 1.388 & 32.891 & 42.001 & 35.685 \\
\hline Panel 4 & Quarterly & Gestation & Low Birth & Fetal \\
\hline$\overline{\text { year }}$ & IMR & $<37$ weeks & Weight & Deaths \\
\hline 1989 & 2.16 & 95.67 & 51.11 & 6.49 \\
\hline 1990 & 1.97 & 93.31 & 48.73 & 6.27 \\
\hline 1991 & 1.87 & 92.39 & 47.91 & 6.04 \\
\hline 1992 & 1.69 & 91.73 & 48.76 & 5.92 \\
\hline 1993 & 1.67 & 92.73 & 48.98 & 5.78 \\
\hline 1994 & 1.66 & 92.22 & 49.94 & 5.75 \\
\hline 1995 & 1.51 & 92.15 & 48.86 & 5.86 \\
\hline 1996 & 1.41 & 92.23 & 48.80 & 5.88 \\
\hline 1997 & 1.40 & 92.08 & 48.56 & 5.40 \\
\hline 1999 & 1.32 & 92.56 & 47.04 & 5.36 \\
\hline 2000 & 1.35 & 91.28 & 47.72 & 5.60 \\
\hline \multicolumn{5}{|c|}{ National Ambient Air Quality Standards } \\
\hline \multirow[t]{2}{*}{$\mathrm{CO}$} & $9.5 \mathrm{ppm}$ & 8-hr & & \\
\hline & $35.5 \mathrm{ppm}$ & $1-\mathrm{hr}$ & & \\
\hline PM10 & $155 \mathrm{ug} / \mathrm{m} 3$ & 24-hr & & \\
\hline NO2 & 54 ppb & annual & & \\
\hline \multirow[t]{2}{*}{$\mathrm{O} 3$} & $85 \mathrm{ppb}$ & 8-hr & & \\
\hline & $125 \mathrm{ppb}$ & $1-\mathrm{hr}$ & & \\
\hline
\end{tabular}

Note: What we refer to as the quarterly IMR is the number of infants $<12$ months old who died in a quarter. 
Table 2: Pollution Levels for Bottom, Middle, and Top Third of Zipcode-Years Ranked by Mean Pollution Levels

\begin{tabular}{|c|c|c|c|}
\hline Variable & bottom $1 / 3$ & middle $1 / 3$ & top $1 / 3$ \\
\hline CO 8-hr & 1.157 & 1.883 & 2.786 \\
\hline PM10 24-hr & 25.136 & 39.036 & 53.580 \\
\hline NO2 1-hr & 30.972 & 49.538 & 68.865 \\
\hline O3 8-hr & 33.698 & 40.095 & 47.136 \\
\hline quarterly IMR & 1.512 & 1.788 & 1.965 \\
\hline gestation<37 per 1,000 & 78.385 & 89.626 & 92.388 \\
\hline low BW per 1,000 & 43.281 & 47.243 & 48.673 \\
\hline fetal death per 1,000 & 5.129 & 5.743 & 5.862 \\
\hline$\%$ male & 0.488 & 0.488 & 0.489 \\
\hline$\%$ black & 0.064 & 0.071 & 0.078 \\
\hline$\%$ hispanic & 0.256 & 0.393 & 0.440 \\
\hline$\%$ asian & 0.134 & 0.108 & 0.099 \\
\hline$\%$ other race & 0.015 & 0.008 & 0.006 \\
\hline$\%$ married & 0.742 & 0.700 & 0.669 \\
\hline$\%$ foreign mom & 0.333 & 0.416 & 0.455 \\
\hline$\%$ racial diff $b / w$ parents & 0.185 & 0.172 & 0.154 \\
\hline$\%$ HS dropout & 0.216 & 0.285 & 0.326 \\
\hline$\%$ HS grads & 0.334 & 0.339 & 0.344 \\
\hline$\%$ AD degree & 0.153 & 0.140 & 0.134 \\
\hline$\%$ college grads & 0.297 & 0.236 & 0.196 \\
\hline$\%$ teen mothers & 0.055 & 0.064 & 0.070 \\
\hline$\%$ age 19 to 25 & 0.267 & 0.303 & 0.325 \\
\hline$\%$ age 26 to 30 & 0.276 & 0.282 & 0.288 \\
\hline$\%$ age 31 to 35 & 0.258 & 0.230 & 0.214 \\
\hline$\%$ age $>=36$ & 0.144 & 0.121 & 0.103 \\
\hline$\%$ first born & 0.431 & 0.413 & 0.408 \\
\hline$\%$ second born & 0.323 & 0.310 & 0.304 \\
\hline$\%$ third born & 0.148 & 0.159 & 0.162 \\
\hline$\%$ gov't insurance & 0.338 & 0.408 & 0.416 \\
\hline$\%$ prenatal care in 1 st trimester & 0.826 & 0.807 & 0.769 \\
\hline
\end{tabular}

Average Zipcode Pollution Levels by Individual Race and Education:

\begin{tabular}{l|cccc} 
& O3 & NO2 & CO & PM \\
\hline All & 40.274 & 51.156 & 1.968 & 39.090 \\
Blacks & 38.135 & 51.916 & 2.124 & 38.878 \\
Non-blacks & 40.464 & 51.088 & 1.954 & 39.109 \\
$<$ HS & 40.664 & 54.495 & 2.118 & 41.103 \\
$>=$ HS & 40.068 & 49.391 & 1.889 & 38.026
\end{tabular}

Sample Statistics:

\begin{tabular}{l|ccc} 
& Total births & Total deaths & IMR per 1000 \\
\hline All & $4,720,190$ & 26,111 & 5.53 \\
Blacks & 384,711 & 4,495 & 11.68 \\
Non-blacks & $4,335,479$ & 21,616 & 4.99 \\
< HS & $1,632,097$ & 10,613 & 6.50 \\
>= HS & $3,088,093$ & 15,498 & 5.02
\end{tabular}


Table 3: The Effect of Pollution on the Probability of Short Gestation

Pollution Measure=Average During Last Month of Pregnancy

\begin{tabular}{|c|c|c|c|c|c|c|c|c|c|c|c|c|}
\hline & $\begin{array}{c}1 \\
c S\end{array}$ & $\begin{array}{c}2 \\
\mathrm{CS}\end{array}$ & $\begin{array}{c}3 \\
\text { cS }\end{array}$ & $\begin{array}{c}4 \\
\text { cS }\end{array}$ & $\begin{array}{c}5 \\
\text { CS }\end{array}$ & $\begin{array}{c}6 \\
\text { CS }\end{array}$ & $\begin{array}{r}7 \\
\text { FE }\end{array}$ & $\begin{array}{r}8 \\
F E\end{array}$ & $\begin{array}{c}9 \\
\text { FE }\end{array}$ & $\begin{array}{r}10 \\
\text { FE }\end{array}$ & $\begin{array}{l}11 \\
\text { FE }\end{array}$ & $\begin{array}{l}12 \\
\text { FE }\end{array}$ \\
\hline$\overline{\mathrm{CO}}$ & $\begin{array}{c}0.867 \\
{[0.502]}\end{array}$ & & & & $\begin{array}{c}0.005 \\
{[0.870]}\end{array}$ & $\begin{array}{c}0.293 \\
{[0.587]}\end{array}$ & $\begin{array}{c}0.248 \\
{[3.022]}\end{array}$ & & & & $\begin{array}{c}0.211 \\
{[1.0971}\end{array}$ & $\begin{array}{c}0.387 \\
{[2.3871}\end{array}$ \\
\hline PM10 & & $\begin{array}{l}0.211^{* *} \\
{[0.033]}\end{array}$ & & & $\begin{array}{l}0.162^{* *} \\
{[0.042]}\end{array}$ & $\begin{array}{l}0.167^{* *} \\
{[0.041]}\end{array}$ & & $\begin{array}{c}0.087 \\
{[0.137]}\end{array}$ & & & $\begin{array}{c}0.061 \\
{[0.086]}\end{array}$ & $\begin{array}{l}0.065 \\
{[0.108]}\end{array}$ \\
\hline $\mathrm{NO} 2$ & & & $\begin{array}{l}0.094^{* *} \\
{[0.028]}\end{array}$ & & $\begin{array}{c}0.022 \\
{[0.051]}\end{array}$ & & & & $\begin{array}{c}0.054 \\
{[0.268]}\end{array}$ & & $\begin{array}{c}0.021 \\
{[0.284]}\end{array}$ & \\
\hline Ozone & & & & $\begin{array}{l}0.167^{* *} \\
{[0.039]}\end{array}$ & $\begin{array}{l}0.110^{*} \\
{[0.048]}\end{array}$ & $\begin{array}{l}0.117^{* *} \\
{[0.045]}\end{array}$ & & & & $\begin{array}{c}0.087 \\
{[0.154]}\end{array}$ & $\begin{array}{c}0.078 \\
{[0.186]}\end{array}$ & $\begin{array}{c}0.084 \\
{[0.135]}\end{array}$ \\
\hline $\begin{array}{l}\text { Max temp. last } \\
30 \text { days }\end{array}$ & $\begin{array}{l}-0.078 \\
{[0.078]}\end{array}$ & $\begin{array}{c}-0.200^{*} \\
{[0.082]}\end{array}$ & $\begin{array}{l}-0.141 \\
{[0.082]}\end{array}$ & $\begin{array}{c}-0.336^{* *} \\
{[0.098]}\end{array}$ & $\begin{array}{c}-0.360^{* *} \\
{[0.101]}\end{array}$ & $\begin{array}{c}-0.354^{* *} \\
{[0.100]}\end{array}$ & $\begin{array}{l}-0.415 \\
{[0.434]}\end{array}$ & $\begin{array}{l}-0.441 \\
{[0.485]}\end{array}$ & $\begin{array}{l}-0.435 \\
{[0.516]}\end{array}$ & $\begin{array}{l}-0.534 \\
{[0.494]}\end{array}$ & $\begin{array}{l}-0.536 \\
{[0.510]}\end{array}$ & $\begin{array}{l}-0.531 \\
{[0.496]}\end{array}$ \\
\hline $\begin{array}{l}\text { Avg. Precip. } \\
\text { last } 30 \text { days }\end{array}$ & $\begin{array}{l}-0.167^{*} \\
{[0.077]}\end{array}$ & $\begin{array}{l}-0.083 \\
{[0.077]}\end{array}$ & $\begin{array}{l}-0.153^{*} \\
{[0.077]}\end{array}$ & $\begin{array}{l}-0.195^{*} \\
{[0.076]}\end{array}$ & $\begin{array}{l}-0.118 \\
{[0.079]}\end{array}$ & $\begin{array}{l}-0.118 \\
{[0.079]}\end{array}$ & $\begin{array}{l}-0.193 \\
{[0.219]}\end{array}$ & $\begin{array}{l}-0.155 \\
{[0.213]}\end{array}$ & $\begin{array}{l}-0.182 \\
{[0.228]}\end{array}$ & $\begin{array}{l}-0.204 \\
{[0.210]}\end{array}$ & $\begin{array}{c}-0.172 \\
{[0.241]}\end{array}$ & $\begin{array}{l}-0.173 \\
{[0.229]}\end{array}$ \\
\hline Infant Character & ics & & & & & & & & & & & \\
\hline Male & $\begin{array}{c}-0.012^{* *} \\
{[0.001]}\end{array}$ & $\begin{array}{c}-0.012^{* *} \\
{[0.001]}\end{array}$ & $\begin{array}{c}-0.012^{* *} \\
{[0.001]}\end{array}$ & $\begin{array}{c}-0.012^{* *} \\
{[0.001]}\end{array}$ & $\begin{array}{c}-0.012^{* *} \\
{[0.001]}\end{array}$ & $\begin{array}{c}-0.012^{* *} \\
{[0.001]}\end{array}$ & $\begin{array}{c}-0.012^{* *} \\
{[0.001]}\end{array}$ & $\begin{array}{c}-0.012^{* *} \\
{[0.001]}\end{array}$ & $\begin{array}{c}-0.012^{* *} \\
{[0.001]}\end{array}$ & $\begin{array}{c}-0.012^{* *} \\
{[0.001]}\end{array}$ & $\begin{array}{c}-0.012^{* *} \\
{[0.001]}\end{array}$ & $\begin{array}{c}-0.012^{* *} \\
{[0.001]}\end{array}$ \\
\hline first birth & $\begin{array}{c}-0.018^{* *} \\
{[0.002]}\end{array}$ & $\begin{array}{c}-0.018^{* *} \\
{[0.002]}\end{array}$ & $\begin{array}{l}-0.018^{* *} \\
{[0.002]}\end{array}$ & $\begin{array}{c}-0.017^{* *} \\
{[0.002]}\end{array}$ & $\begin{array}{c}-0.018^{* *} \\
{[0.002]}\end{array}$ & $\begin{array}{c}-0.018^{* *} \\
{[0.002]}\end{array}$ & $\begin{array}{c}-0.016^{* *} \\
{[0.002]}\end{array}$ & $\begin{array}{c}-0.016^{* *} \\
{[0.002]}\end{array}$ & $\begin{array}{c}-0.016^{* *} \\
{[0.002]}\end{array}$ & $\begin{array}{c}-0.016^{* *} \\
{[0.002]}\end{array}$ & $\begin{array}{c}-0.016^{* *} \\
{[0.002]}\end{array}$ & $\begin{array}{c}-0.016^{* *} \\
{[0.002]}\end{array}$ \\
\hline second birth & $\begin{array}{c}-0.022^{* *} \\
{[0.002]}\end{array}$ & $\begin{array}{c}-0.022^{* *} \\
{[0.002]}\end{array}$ & $\begin{array}{c}-0.022^{* *} \\
{[0.002]}\end{array}$ & $\begin{array}{c}-0.022^{* *} \\
{[0.002]}\end{array}$ & $\begin{array}{c}-0.022^{* *} \\
{[0.002]}\end{array}$ & $\begin{array}{c}-0.022^{* *} \\
{[0.002]}\end{array}$ & $\begin{array}{c}-0.021^{* *} \\
{[0.002]}\end{array}$ & $\begin{array}{c}-0.021^{* *} \\
{[0.002]}\end{array}$ & $\begin{array}{c}-0.021^{* *} \\
{[0.002]}\end{array}$ & $\begin{array}{c}-0.020^{* *} \\
{[0.002]}\end{array}$ & $\begin{array}{c}-0.021^{* *} \\
{[0.002]}\end{array}$ & $\begin{array}{c}-0.021^{* *} \\
{[0.002]}\end{array}$ \\
\hline third birth & $\begin{array}{c}-0.017^{* *} \\
{[0.002]}\end{array}$ & $\begin{array}{c}-0.017^{* *} \\
{[0.002]}\end{array}$ & $\begin{array}{c}-0.017^{* *} \\
{[0.002]}\end{array}$ & $\begin{array}{c}-0.016^{* *} \\
{[0.002]}\end{array}$ & $\begin{array}{c}-0.017^{* *} \\
{[0.002]}\end{array}$ & $\begin{array}{c}-0.017^{* *} \\
{[0.002]}\end{array}$ & $\begin{array}{c}-0.016^{* *} \\
{[0.002]}\end{array}$ & $\begin{array}{c}-0.016^{* *} \\
{[0.002]}\end{array}$ & $\begin{array}{c}-0.016^{* *} \\
{[0.002]}\end{array}$ & $\begin{array}{c}-0.015^{\star *} \\
{[0.002]}\end{array}$ & $\begin{array}{c}-0.016^{* *} \\
{[0.002]}\end{array}$ & $\begin{array}{c}-0.016^{* *} \\
{[0.002]}\end{array}$ \\
\hline Mother & stics & & & & & & & & & & & \\
\hline Black & $\begin{array}{l}0.056^{* *} \\
{[0.002]}\end{array}$ & $\begin{array}{l}0.056^{* *} \\
{[0.002]}\end{array}$ & $\begin{array}{l}0.055^{\star *} \\
{[0.002]}\end{array}$ & $\begin{array}{l}0.056^{* *} \\
{[0.002]}\end{array}$ & $\begin{array}{l}0.056^{* *} \\
{[0.002]}\end{array}$ & $\begin{array}{l}0.056^{* *} \\
{[0.002]}\end{array}$ & $\begin{array}{l}0.052^{* *} \\
{[0.002]}\end{array}$ & $\begin{array}{l}0.052^{* *} \\
{[0.002]}\end{array}$ & $\begin{array}{l}0.052^{* *} \\
{[0.002]}\end{array}$ & $\begin{array}{l}0.052^{* *} \\
{[0.002]}\end{array}$ & $\begin{array}{l}0.052^{* *} \\
{[0.002]}\end{array}$ & $\begin{array}{l}0.052^{* *} \\
{[0.002]}\end{array}$ \\
\hline Hispanic & $\begin{array}{l}0.010^{* *} \\
{[0.001]}\end{array}$ & $\begin{array}{l}0.009^{* *} \\
{[0.001]}\end{array}$ & $\begin{array}{l}0.009^{* *} \\
{[0.001]}\end{array}$ & $\begin{array}{l}0.010^{* *} \\
{[0.001]}\end{array}$ & $\begin{array}{l}0.009^{* *} \\
{[0.001]}\end{array}$ & $\begin{array}{l}0.009^{* *} \\
{[0.001]}\end{array}$ & $\begin{array}{l}0.008^{* *} \\
{[0.001]}\end{array}$ & $\begin{array}{l}0.007^{* *} \\
{[0.001]}\end{array}$ & $\begin{array}{l}0.008^{* *} \\
{[0.001]}\end{array}$ & $\begin{array}{l}0.008^{* *} \\
{[0.001]}\end{array}$ & $\begin{array}{l}0.007^{* *} \\
{[0.001]}\end{array}$ & $\begin{array}{l}0.007^{* *} \\
{[0.001]}\end{array}$ \\
\hline Asian & $\begin{array}{l}0.022^{* *} \\
{[0.002]}\end{array}$ & $\begin{array}{l}0.022^{* *} \\
{[0.002]}\end{array}$ & $\begin{array}{l}0.022^{* *} \\
{[0.002]}\end{array}$ & $\begin{array}{l}0.022^{* *} \\
{[0.002]}\end{array}$ & $\begin{array}{l}0.022^{* *} \\
{[0.002]}\end{array}$ & $\begin{array}{l}0.022^{* *} \\
{[0.002]}\end{array}$ & $\begin{array}{l}0.023^{\star *} \\
{[0.002]}\end{array}$ & $\begin{array}{l}0.022^{* *} \\
{[0.002]}\end{array}$ & $\begin{array}{l}0.023^{\star *} \\
{[0.002]}\end{array}$ & $\begin{array}{l}0.023^{\star *} \\
{[0.002]}\end{array}$ & $\begin{array}{l}0.022^{* *} \\
{[0.002]}\end{array}$ & $\begin{array}{l}0.022^{* *} \\
{[0.002]}\end{array}$ \\
\hline Other Race & $\begin{array}{c}0.01 \\
{[0.005]}\end{array}$ & $\begin{array}{c}0.01 \\
{[0.005]}\end{array}$ & $\begin{array}{c}0.01 \\
{[0.005]}\end{array}$ & $\begin{array}{c}0.010^{*} \\
{[0.005]}\end{array}$ & $\begin{array}{c}0.009 \\
{[0.005]}\end{array}$ & $\begin{array}{c}0.009 \\
{[0.005]}\end{array}$ & $\begin{array}{c}0.009 \\
{[0.005]}\end{array}$ & $\begin{array}{c}0.009 \\
{[0.005]}\end{array}$ & $\begin{array}{c}0.009 \\
{[0.005]}\end{array}$ & $\begin{array}{c}0.01 \\
{[0.005]}\end{array}$ & $\begin{array}{c}0.008 \\
{[0.005]}\end{array}$ & $\begin{array}{c}0.008 \\
{[0.005]}\end{array}$ \\
\hline Married & $\begin{array}{c}-0.013^{* *} \\
{[0.002]}\end{array}$ & $\begin{array}{c}-0.013^{* *} \\
{[0.002]}\end{array}$ & $\begin{array}{c}-0.013^{* *} \\
{[0.002]}\end{array}$ & $\begin{array}{c}-0.013^{* *} \\
{[0.002]}\end{array}$ & $\begin{array}{c}-0.013^{* *} \\
{[0.002]}\end{array}$ & $\begin{array}{c}-0.013^{* *} \\
{[0.002]}\end{array}$ & $\begin{array}{c}-0.013^{* *} \\
{[0.002]}\end{array}$ & $\begin{array}{c}-0.013^{* *} \\
{[0.002]}\end{array}$ & $\begin{array}{c}-0.013^{* *} \\
{[0.002]}\end{array}$ & $\begin{array}{c}-0.013^{* *} \\
{[0.002]}\end{array}$ & $\begin{array}{c}-0.013^{* *} \\
{[0.002]}\end{array}$ & $\begin{array}{c}-0.013^{* *} \\
{[0.002]}\end{array}$ \\
\hline Foreign Born & $\begin{array}{c}-0.009^{* *} \\
{[0.001]}\end{array}$ & $\begin{array}{c}-0.009^{* *} \\
{[0.001]}\end{array}$ & $\begin{array}{c}-0.009^{* *} \\
{[0.001]}\end{array}$ & $\begin{array}{c}-0.009^{* *} \\
{[0.001]}\end{array}$ & $\begin{array}{c}-0.009^{* *} \\
{[0.001]}\end{array}$ & $\begin{array}{c}-0.009^{* *} \\
{[0.001]}\end{array}$ & $\begin{array}{c}-0.009^{* *} \\
{[0.001]}\end{array}$ & $\begin{array}{c}-0.009^{* *} \\
{[0.001]}\end{array}$ & $\begin{array}{c}-0.009^{* *} \\
{[0.001]}\end{array}$ & $\begin{array}{c}-0.009^{* *} \\
{[0.001]}\end{array}$ & $\begin{array}{c}-0.009^{* *} \\
{[0.001]}\end{array}$ & $\begin{array}{c}-0.009^{* *} \\
{[0.001]}\end{array}$ \\
\hline $\begin{array}{l}\text { Parents of } \\
\text { Different Race }\end{array}$ & $\begin{array}{l}0.008^{* *} \\
{[0.001]}\end{array}$ & $\begin{array}{l}0.008^{* *} \\
{[0.001]}\end{array}$ & $\begin{array}{l}0.008^{* *} \\
{[0.001]}\end{array}$ & $\begin{array}{l}0.008^{* *} \\
{[0.001]}\end{array}$ & $\begin{array}{l}0.008^{* *} \\
{[0.001]}\end{array}$ & $\begin{array}{l}0.008^{* *} \\
{[0.001]}\end{array}$ & $\begin{array}{l}0.009^{* *} \\
{[0.001]}\end{array}$ & $\begin{array}{l}0.009^{* *} \\
{[0.001]}\end{array}$ & $\begin{array}{l}0.009^{* *} \\
{[0.001]}\end{array}$ & $\begin{array}{l}0.009^{* *} \\
{[0.001]}\end{array}$ & $\begin{array}{l}0.009^{* *} \\
{[0.001]}\end{array}$ & $\begin{array}{l}0.009^{* *} \\
{[0.001]}\end{array}$ \\
\hline
\end{tabular}


Table 3: The Effect of Pollution on the Probability of Short Gestation (continued)

Pollution Measure=Average During Last Month of Pregnancy

\begin{tabular}{|c|c|c|c|c|c|c|c|c|c|c|c|c|}
\hline & $\begin{array}{c}1 \\
c s\end{array}$ & $\begin{array}{c}2 \\
\mathrm{CS}\end{array}$ & $\begin{array}{c}3 \\
\mathrm{CS}\end{array}$ & $\begin{array}{c}4 \\
\mathrm{CS}\end{array}$ & $\begin{array}{c}5 \\
\mathrm{CS}\end{array}$ & $\begin{array}{c}6 \\
\mathrm{CS}\end{array}$ & $\begin{array}{c}7 \\
\text { FE }\end{array}$ & $\begin{array}{r}8 \\
\mathrm{FE}\end{array}$ & $\begin{array}{c}9 \\
\text { FE }\end{array}$ & $\begin{array}{r}10 \\
\text { FE }\end{array}$ & $\begin{array}{r}11 \\
\mathrm{FE}\end{array}$ & $\begin{array}{l}12 \\
\mathrm{FE}\end{array}$ \\
\hline HS Graduate & $\begin{array}{c}-0.010^{* *} \\
{[0.001]}\end{array}$ & $\begin{array}{c}-0.010^{* *} \\
{[0.001]}\end{array}$ & $\begin{array}{c}-0.009^{* *} \\
{[0.001]}\end{array}$ & $\begin{array}{c}-0.010^{* *} \\
{[0.001]}\end{array}$ & $\begin{array}{c}-0.010^{* *} \\
{[0.001]}\end{array}$ & $\begin{array}{c}-0.010^{* *} \\
{[0.001]}\end{array}$ & $\begin{array}{c}-0.009^{* *} \\
{[0.001]}\end{array}$ & $\begin{array}{c}-0.009^{* *} \\
{[0.001]}\end{array}$ & $\begin{array}{c}-0.009^{* *} \\
{[0.001]}\end{array}$ & $\begin{array}{c}-0.009^{* *} \\
{[0.001]}\end{array}$ & $\begin{array}{c}-0.009^{* *} \\
{[0.001]}\end{array}$ & $\begin{array}{c}-0.009^{* *} \\
{[0.001]}\end{array}$ \\
\hline Some College & $\begin{array}{c}-0.015^{\star \star} \\
{[0.002]}\end{array}$ & $\begin{array}{c}-0.014^{* *} \\
{[0.002]}\end{array}$ & $\begin{array}{c}-0.015^{\star *} \\
{[0.002]}\end{array}$ & $\begin{array}{c}-0.015^{\star *} \\
{[0.002]}\end{array}$ & $\begin{array}{c}-0.015^{\star *} \\
{[0.002]}\end{array}$ & $\begin{array}{c}-0.015^{\star *} \\
{[0.002]}\end{array}$ & $\begin{array}{c}-0.013^{* *} \\
{[0.002]}\end{array}$ & $\begin{array}{c}-0.013^{* *} \\
{[0.002]}\end{array}$ & $\begin{array}{c}-0.013^{* *} \\
{[0.002]}\end{array}$ & $\begin{array}{c}-0.013^{\star *} \\
{[0.002]}\end{array}$ & $\begin{array}{c}-0.013^{* *} \\
{[0.002]}\end{array}$ & $\begin{array}{c}-0.013^{* *} \\
{[0.002]}\end{array}$ \\
\hline College Grad. & $\begin{array}{c}-0.024^{\star *} \\
{[0.002]}\end{array}$ & $\begin{array}{c}-0.024^{* *} \\
{[0.002]}\end{array}$ & $\begin{array}{c}-0.024^{\star *} \\
{[0.002]}\end{array}$ & $\begin{array}{c}-0.024^{* *} \\
{[0.002]}\end{array}$ & $\begin{array}{c}-0.024^{* *} \\
{[0.002]}\end{array}$ & $\begin{array}{c}-0.024^{* *} \\
{[0.002]}\end{array}$ & $\begin{array}{c}-0.021^{* *} \\
{[0.002]}\end{array}$ & $\begin{array}{c}-0.021^{* *} \\
{[0.002]}\end{array}$ & $\begin{array}{c}-0.021^{* *} \\
{[0.002]}\end{array}$ & $\begin{array}{c}-0.021^{* *} \\
{[0.002]}\end{array}$ & $\begin{array}{c}-0.022^{* *} \\
{[0.002]}\end{array}$ & $\begin{array}{c}-0.022^{* *} \\
{[0.002]}\end{array}$ \\
\hline $\begin{array}{l}\text { Parents Diff. } \\
\text { Education }\end{array}$ & $\begin{array}{c}0.002^{*} \\
{[0.001]}\end{array}$ & $\begin{array}{l}0.002^{*} \\
{[0.001]}\end{array}$ & $\begin{array}{l}0.002^{*} \\
{[0.001]}\end{array}$ & $\begin{array}{c}0.002^{*} \\
{[0.001]}\end{array}$ & $\begin{array}{c}0.002^{*} \\
{[0.001]}\end{array}$ & $\begin{array}{c}0.002^{*} \\
{[0.001]}\end{array}$ & $\begin{array}{c}0.002^{*} \\
{[0.001]}\end{array}$ & $\begin{array}{c}0.002^{*} \\
{[0.001]}\end{array}$ & $\begin{array}{l}0.002^{*} \\
{[0.001]}\end{array}$ & $\begin{array}{c}0.002^{*} \\
{[0.001]}\end{array}$ & $\begin{array}{c}0.002^{*} \\
{[0.001]}\end{array}$ & $\begin{array}{c}0.002^{*} \\
{[0.001]}\end{array}$ \\
\hline 19 to 25 & $\begin{array}{c}-0.019^{* *} \\
{[0.002]}\end{array}$ & $\begin{array}{c}-0.019^{* *} \\
{[0.002]}\end{array}$ & $\begin{array}{c}-0.019^{* *} \\
{[0.002]}\end{array}$ & $\begin{array}{c}-0.019^{* *} \\
{[0.002]}\end{array}$ & $\begin{array}{c}-0.018^{* *} \\
{[0.002]}\end{array}$ & $\begin{array}{c}-0.019^{* *} \\
{[0.002]}\end{array}$ & $\begin{array}{c}-0.019^{* *} \\
{[0.002]}\end{array}$ & $\begin{array}{c}-0.018^{* *} \\
{[0.002]}\end{array}$ & $\begin{array}{c}-0.019^{* *} \\
{[0.002]}\end{array}$ & $\begin{array}{c}-0.019^{* *} \\
{[0.002]}\end{array}$ & $\begin{array}{c}-0.018^{* *} \\
{[0.002]}\end{array}$ & $\begin{array}{c}-0.018^{* *} \\
{[0.002]}\end{array}$ \\
\hline 26 to 30 & $\begin{array}{c}-0.020^{* *} \\
{[0.002]}\end{array}$ & $\begin{array}{c}-0.019^{* *} \\
{[0.002]}\end{array}$ & $\begin{array}{c}-0.020^{* *} \\
{[0.002]}\end{array}$ & $\begin{array}{c}-0.020^{* *} \\
{[0.002]}\end{array}$ & $\begin{array}{c}-0.019^{* *} \\
{[0.002]}\end{array}$ & $\begin{array}{c}-0.019^{* *} \\
{[0.002]}\end{array}$ & $\begin{array}{c}-0.019^{* *} \\
{[0.002]}\end{array}$ & $\begin{array}{c}-0.018^{* *} \\
{[0.002]}\end{array}$ & $\begin{array}{c}-0.019^{* *} \\
{[0.002]}\end{array}$ & $\begin{array}{c}-0.019^{* *} \\
{[0.002]}\end{array}$ & $\begin{array}{c}-0.018^{* *} \\
{[0.002]}\end{array}$ & $\begin{array}{c}-0.018^{\star *} \\
{[0.002]}\end{array}$ \\
\hline 31 to 35 & $\begin{array}{c}-0.012^{* *} \\
{[0.002]}\end{array}$ & $\begin{array}{c}-0.012^{* *} \\
{[0.002]}\end{array}$ & $\begin{array}{c}-0.013^{* *} \\
{[0.002]}\end{array}$ & $\begin{array}{c}-0.013^{* *} \\
{[0.002]}\end{array}$ & $\begin{array}{c}-0.012^{* *} \\
{[0.002]}\end{array}$ & $\begin{array}{c}-0.012^{* *} \\
{[0.002]}\end{array}$ & $\begin{array}{c}-0.011^{* *} \\
{[0.002]}\end{array}$ & $\begin{array}{c}-0.011^{* *} \\
{[0.002]}\end{array}$ & $\begin{array}{c}-0.011^{* *} \\
{[0.002]}\end{array}$ & $\begin{array}{c}-0.011^{* *} \\
{[0.002]}\end{array}$ & $\begin{array}{c}-0.010^{* *} \\
{[0.002]}\end{array}$ & $\begin{array}{c}-0.010^{* *} \\
{[0.002]}\end{array}$ \\
\hline$>36$ & $\begin{array}{c}0.004 \\
{[0.003]}\end{array}$ & $\begin{array}{c}0.005 \\
{[0.003]}\end{array}$ & $\begin{array}{c}0.004 \\
{[0.003]}\end{array}$ & $\begin{array}{c}0.004 \\
{[0.003]}\end{array}$ & $\begin{array}{c}0.005 \\
{[0.003]}\end{array}$ & $\begin{array}{c}0.005 \\
{[0.003]}\end{array}$ & $\begin{array}{c}0.006^{*} \\
{[0.003]}\end{array}$ & $\begin{array}{l}0.006^{*} \\
{[0.003]}\end{array}$ & $\begin{array}{l}0.006^{*} \\
{[0.003]}\end{array}$ & $\begin{array}{l}0.006^{*} \\
{[0.003]}\end{array}$ & $\begin{array}{c}0.007^{\star} \\
{[0.003]}\end{array}$ & $\begin{array}{c}0.006^{*} \\
{[0.003]}\end{array}$ \\
\hline gov't insurance & $\begin{array}{l}0.013^{* *} \\
{[0.001]}\end{array}$ & $\begin{array}{l}0.013^{* *} \\
{[0.001]}\end{array}$ & $\begin{array}{l}0.013^{* *} \\
{[0.001]}\end{array}$ & $\begin{array}{l}0.013^{\star *} \\
{[0.001]}\end{array}$ & $\begin{array}{l}0.013^{* *} \\
{[0.001]}\end{array}$ & $\begin{array}{l}0.013^{* *} \\
{[0.001]}\end{array}$ & $\begin{array}{l}0.011^{* *} \\
{[0.001]}\end{array}$ & $\begin{array}{l}0.011^{* *} \\
{[0.001]}\end{array}$ & $\begin{array}{l}0.011^{* *} \\
{[0.001]}\end{array}$ & $\begin{array}{l}0.011^{* *} \\
{[0.001]}\end{array}$ & $\begin{array}{l}0.011^{\star *} \\
{[0.001]}\end{array}$ & $\begin{array}{l}0.011^{* *} \\
{[0.001]}\end{array}$ \\
\hline $\begin{array}{l}\text { prenatal care } \\
\text { 1st trimester }\end{array}$ & $\begin{array}{c}-0.024^{* *} \\
{[0.001]}\end{array}$ & $\begin{array}{c}-0.024^{* *} \\
{[0.001]}\end{array}$ & $\begin{array}{c}-0.024^{* *} \\
{[0.001]}\end{array}$ & $\begin{array}{c}-0.024^{* *} \\
{[0.001]}\end{array}$ & $\begin{array}{c}-0.023^{* *} \\
{[0.001]}\end{array}$ & $\begin{array}{c}-0.023^{* *} \\
{[0.001]}\end{array}$ & $\begin{array}{c}-0.023^{* *} \\
{[0.001]}\end{array}$ & $\begin{array}{c}-0.023^{* *} \\
{[0.001]}\end{array}$ & $\begin{array}{c}-0.023^{* *} \\
{[0.001]}\end{array}$ & $\begin{array}{c}-0.023^{* *} \\
{[0.001]}\end{array}$ & $\begin{array}{c}-0.023^{* *} \\
{[0.001]}\end{array}$ & $\begin{array}{c}-0.023^{* *} \\
{[0.001]}\end{array}$ \\
\hline Observations & 452148 & 453073 & 454580 & 458897 & 449239 & 449426 & 452148 & 453073 & 454580 & 458897 & 449239 & 449426 \\
\hline R-squared & 0.01 & 0.01 & 0.01 & 0.01 & 0.01 & 0.01 & 0.01 & 0.01 & 0.01 & 0.01 & 0.01 & 0.01 \\
\hline
\end{tabular}

Notes: Robust standard errors are in brackets. $A$ * indicates significance at the $5 \%$ level. $A$ ** indicates significance at the $1 \%$ level.

Coefficients and standard errors are multiplied by 1,000 . CS indicates that the model is cross sectional while FE indicates fixed effects. 
Table 4: The Effect of Pollution on Other Pregnancy Outcomes

\begin{tabular}{|c|c|c|c|c|c|c|c|c|c|c|c|c|}
\hline & $\begin{array}{r}1 \\
C S\end{array}$ & $\begin{array}{c}2 \\
C S\end{array}$ & $\begin{array}{r}3 \\
\text { CS }\end{array}$ & $\begin{array}{c}4 \\
C S\end{array}$ & $\begin{array}{r}5 \\
C S\end{array}$ & $\begin{array}{r}6 \\
C S\end{array}$ & $\begin{array}{r}7 \\
\mathrm{FE} \\
\end{array}$ & $\begin{array}{r}8 \\
F E\end{array}$ & $\begin{array}{c}9 \\
\text { FE }\end{array}$ & $\begin{array}{r}10 \\
\mathrm{FE}\end{array}$ & $\begin{array}{r}11 \\
\mathrm{FE}\end{array}$ & $\begin{array}{l}12 \\
\mathrm{FE}\end{array}$ \\
\hline \multicolumn{13}{|c|}{ 1. Dependent Variable=Low Birthweight, Pollution Measure=Average During Last Month of Pregnancy } \\
\hline \multirow[t]{2}{*}{$\mathrm{CO}$} & 0.596 & & & & $1.439^{*}$ & 0.379 & 0.451 & & & & $1.699^{*}$ & 0.621 \\
\hline & [0.373] & & & & {$[0.655]$} & [0.439] & [1.237] & & & & {$[0.750]$} & [1.050] \\
\hline \multirow[t]{2}{*}{ PM10 } & & $0.051^{*}$ & & & 0.055 & 0.036 & & 0.001 & & & 0.003 & -0.019 \\
\hline & & {$[0.025]$} & & & {$[0.031]$} & {$[0.030]$} & & {$[0.058]$} & & & {$[0.045]$} & {$[0.050]$} \\
\hline \multirow[t]{2}{*}{ NO2 } & & & 0.016 & & $-0.082^{*}$ & & & & -0.037 & & -0.124 & \\
\hline & & & [0.021] & & {$[0.038]$} & & & & {$[0.107]$} & & {$[0.116]$} & \\
\hline Ozone & & & & $\begin{array}{l}-0.006 \\
{[0.029]}\end{array}$ & $\begin{array}{c}0.022 \\
{[0.036]}\end{array}$ & $\begin{array}{c}-0.003 \\
{[0.034]}\end{array}$ & & & & $\begin{array}{l}-0.015 \\
{[0.066]}\end{array}$ & $\begin{array}{c}0.043 \\
{[0.079]}\end{array}$ & $\begin{array}{c}0.008 \\
{[0.061]}\end{array}$ \\
\hline Observations & 451394 & 452291 & 453826 & 458116 & 448486 & 448673 & 451394 & 452291 & 453826 & 458116 & 448486 & 448673 \\
\hline R-squared & 0.01 & 0.01 & 0.01 & 0.01 & 0.01 & 0.01 & 0.01 & 0.01 & 0.01 & 0.01 & 0.01 & 0.01 \\
\hline \multicolumn{13}{|c|}{ 2. Dependent Variable=Fetal Death, Pollution Measure=Average During Last Month of Pregnancy } \\
\hline $\mathrm{CO}$ & $\begin{array}{c}-0.221 \\
{[0.130]}\end{array}$ & & & & $\begin{array}{c}0.024 \\
{[0.213]}\end{array}$ & $\begin{array}{c}-0.213 \\
{[0.149]}\end{array}$ & $\begin{array}{c}0.044 \\
{[0.200]}\end{array}$ & & & & $\begin{array}{c}-0.05 \\
{[0.218]}\end{array}$ & $\begin{array}{c}0.121 \\
{[0.197]}\end{array}$ \\
\hline PM10 & & $\begin{array}{c}-0.003 \\
{[0.009]}\end{array}$ & & & $\begin{array}{c}0.008 \\
{[0.011]}\end{array}$ & $\begin{array}{c}0.003 \\
{[0.010]}\end{array}$ & & $\begin{array}{c}0.003 \\
{[0.012]}\end{array}$ & & & $\begin{array}{l}-0.005 \\
{[0.012]}\end{array}$ & $\begin{array}{l}-0.002 \\
{[0.012]}\end{array}$ \\
\hline NO2 & & & $\begin{array}{c}-0.014 \\
{[0.007]}\end{array}$ & & $\begin{array}{l}-0.019 \\
{[0.012]}\end{array}$ & & & & $\begin{array}{c}0.013 \\
{[0.017]}\end{array}$ & & $\begin{array}{c}0.02 \\
{[0.022]}\end{array}$ & \\
\hline Ozone & & & & $\begin{array}{c}0.013 \\
{[0.010]}\end{array}$ & $\begin{array}{c}0.011 \\
{[0.012]}\end{array}$ & $\begin{array}{c}0.006 \\
{[0.011]}\end{array}$ & & & & $\begin{array}{c}0.009 \\
{[0.013]}\end{array}$ & $\begin{array}{c}0.007 \\
{[0.015]}\end{array}$ & $\begin{array}{c}0.012 \\
{[0.013]}\end{array}$ \\
\hline Observations & 392981 & 392887 & 394084 & 396931 & 390670 & 390791 & 392981 & 392887 & 394084 & 396931 & 390670 & 390791 \\
\hline R-squared & 0.00 & 0.00 & 0.00 & 0.00 & 0.00 & 0.00 & 0.00 & 0.00 & 0.00 & 0.00 & 0.00 & 0.00 \\
\hline \multicolumn{13}{|c|}{ 3. Dependent Variable=Short Gestation, Pollution Measure=Average During Last Trimester of Pregnancy } \\
\hline $\mathrm{CO}$ & $\begin{array}{c}1.302^{*} \\
{[0.535]}\end{array}$ & & & & $\begin{array}{l}-1.336 \\
{[1.008]}\end{array}$ & $\begin{array}{c}0.287 \\
{[0.647]}\end{array}$ & $\begin{array}{c}0.306 \\
{[3.751]}\end{array}$ & & & & $\begin{array}{c}-1.703 \\
{[2.581]}\end{array}$ & $\begin{array}{c}0.25 \\
{[2.820]}\end{array}$ \\
\hline PM10 & & $\begin{array}{l}0.250^{* *} \\
{[0.037]}\end{array}$ & & & $\begin{array}{l}0.175^{\star *} \\
{[0.051]}\end{array}$ & $\begin{array}{l}0.208^{* \star} \\
{[0.048]}\end{array}$ & & $\begin{array}{c}0.088 \\
{[0.195]}\end{array}$ & & & $\begin{array}{c}0.017 \\
{[0.159]}\end{array}$ & $\begin{array}{c}0.066 \\
{[0.181]}\end{array}$ \\
\hline NO2 & & & $\begin{array}{l}0.145^{\star *} \\
{[0.029]}\end{array}$ & & $\begin{array}{l}0.119^{*} \\
{[0.056]}\end{array}$ & & & & $\begin{array}{c}0.145 \\
{[0.319]}\end{array}$ & & $\begin{array}{c}0.228 \\
{[0.352]}\end{array}$ & \\
\hline Ozone & & & & $\begin{array}{l}0.198^{* *} \\
{[0.045]}\end{array}$ & $\begin{array}{c}0.083 \\
{[0.056]}\end{array}$ & $\begin{array}{c}0.115^{*} \\
{[0.054]}\end{array}$ & & & & $\begin{array}{c}0.085 \\
{[0.202]}\end{array}$ & $\begin{array}{c}0.027 \\
{[0.234]}\end{array}$ & $\begin{array}{c}0.077 \\
{[0.200]}\end{array}$ \\
\hline Observations & 461165 & 461165 & 461165 & 461165 & 461165 & 461165 & 461165 & 461165 & 461165 & 461165 & 461165 & 461165 \\
\hline R-squared & 0.01 & 0.01 & 0.01 & 0.01 & 0.01 & 0.01 & 0.01 & 0.01 & 0.01 & 0.01 & 0.01 & 0.01 \\
\hline
\end{tabular}

Note: Specification is the same as Table 3 . See Table 3 notes. 
Table 5: Differential Effects of Pollution on Birth Outcomes, Zipcode Fixed Effects Models

\begin{tabular}{|c|c|c|c|c|c|c|}
\hline Interaction Variable: & $\begin{array}{c}1 \\
\text { High Poll. }\end{array}$ & $\begin{array}{c}2 \\
\text { High Poll. }\end{array}$ & $\begin{array}{r}3 \\
<\mathrm{HS} \\
\end{array}$ & $\begin{aligned} & 4 \\
&< H S \\
&\end{aligned}$ & $\begin{array}{c}5 \\
\text { Black } \\
\end{array}$ & $\begin{array}{c}6 \\
\text { Black }\end{array}$ \\
\hline \multicolumn{7}{|c|}{ 1. Dependent Variable=Low Birth Weight } \\
\hline \multirow{2}{*}{$\mathrm{CO}$} & 4.139 & -0.708 & 1.534 & 0.695 & 1.365 & 0.535 \\
\hline & [2.499] & [2.508] & {$[0.896]$} & [1.135] & [0.742] & [1.056] \\
\hline \multirow[t]{2}{*}{ CO*interaction var. } & -1.095 & 0.609 & 0.738 & 0.014 & 1.846 & -0.362 \\
\hline & [1.042] & [0.838] & {$[1.279]$} & [0.804] & [2.970] & [2.013] \\
\hline \multirow[t]{2}{*}{ PM10 } & 0.217 & 0.144 & 0.008 & -0.011 & -0.019 & -0.037 \\
\hline & [0.118] & [0.110] & {$[0.051]$} & [0.054] & [0.046] & [0.051] \\
\hline \multirow[t]{2}{*}{ PM10*interaction var. } & -0.1 & -0.075 & -0.012 & -0.028 & 0.295 & 0.244 \\
\hline & [0.052] & {$[0.047]$} & {$[0.064]$} & [0.061] & [0.156] & [0.150] \\
\hline \multirow[t]{2}{*}{ NO2 } & -0.484 & & -0.106 & & -0.103 & \\
\hline & [0.271] & & {$[0.120]$} & & [0.115] & \\
\hline \multirow[t]{2}{*}{ NO2*interaction var. } & 0.163 & & -0.058 & & -0.189 & \\
\hline & [0.084] & & {$[0.075]$} & & {$[0.177]$} & \\
\hline \multirow[t]{2}{*}{$\mathrm{O} 3$} & 0.053 & -0.071 & 0.001 & -0.027 & 0.05 & 0.022 \\
\hline & [0.178] & [0.165] & {$[0.081]$} & [0.064] & [0.079] & {$[0.061]$} \\
\hline \multirow[t]{2}{*}{ O3*interaction var. } & -0.001 & 0.035 & $0.117^{*}$ & 0.095 & -0.178 & -0.244 \\
\hline & [0.055] & {$[0.054]$} & {$[0.057]$} & [0.052] & [0.139] & {$[0.128]$} \\
\hline \multicolumn{7}{|c|}{ 2. Dependent Variable=Short Gestation } \\
\hline \multirow[t]{2}{*}{$\mathrm{CO}$} & 3.994 & 5.21 & -0.528 & -0.321 & 0.338 & 0.215 \\
\hline & [3.761] & [5.239] & [1.198] & [2.499] & [1.102] & [2.421] \\
\hline \multirow{2}{*}{ CO*interaction var. } & -1.599 & -2.017 & 1.908 & 1.786 & -1.853 & 1.435 \\
\hline & [1.538] & [1.518] & [1.693] & [1.044] & [3.324] & [2.129] \\
\hline \multirow[t]{2}{*}{ PM10 } & -0.006 & 0.01 & 0.085 & 0.089 & 0.059 & 0.057 \\
\hline & [0.212] & [0.197] & {$[0.091]$} & {$[0.110]$} & [0.086] & {$[0.107]$} \\
\hline \multirow[t]{2}{*}{ PM10*interaction var. } & 0.031 & 0.026 & -0.059 & -0.064 & 0.046 & 0.119 \\
\hline & [0.093] & [0.085] & {$[0.086]$} & [0.082] & [0.173] & [0.164] \\
\hline \multirow[t]{2}{*}{ NO2 } & 0.12 & & 0.023 & & 0 & \\
\hline & [0.604] & & {$[0.287]$} & & [0.284] & \\
\hline \multirow[t]{2}{*}{ NO2*interaction var. } & -0.038 & & -0.011 & & 0.275 & \\
\hline & [0.156] & & {$[0.101]$} & & [0.209] & \\
\hline \multirow[t]{2}{*}{$\mathrm{O} 3$} & 0.361 & 0.394 & 0.033 & 0.039 & 0.076 & 0.075 \\
\hline & [0.384] & [0.358] & {$[0.189]$} & [0.140] & [0.186] & [0.135] \\
\hline \multirow[t]{2}{*}{ O3*interaction var. } & -0.114 & -0.124 & 0.124 & 0.122 & 0.003 & 0.095 \\
\hline & [0.100] & [0.104] & {$[0.078]$} & [0.068] & [0.163] & [0.144] \\
\hline \multicolumn{7}{|c|}{ 3. Dependent Variable=Fetal Death } \\
\hline \multirow[t]{2}{*}{$\mathrm{CO}$} & $-1.702^{*}$ & $-1.631^{\star *}$ & -0.424 & -0.102 & -0.119 & 0.128 \\
\hline & [0.774] & {$[0.616]$} & {$[0.264]$} & {$[0.226]$} & [0.229] & {$[0.200]$} \\
\hline CO*interaction var. & $0.655^{\star}$ & $0.706^{* *}$ & $0.862^{*}$ & $0.512^{*}$ & 0.68 & -0.076 \\
\hline & [0.306] & {$[0.236]$} & {$[0.361]$} & {$[0.254]$} & [0.905] & {$[0.637]$} \\
\hline PM10 & 0.029 & 0.024 & 0.001 & 0.007 & -0.009 & -0.004 \\
\hline & {$[0.037]$} & {$[0.036]$} & {$[0.014]$} & {$[0.014]$} & {$[0.012]$} & [0.012] \\
\hline PM10*interaction var. & -0.011 & -0.008 & -0.016 & -0.022 & 0.054 & 0.032 \\
\hline & {$[0.016]$} & [0.015] & {$[0.019]$} & [0.018] & {$[0.050]$} & [0.045] \\
\hline NO2 & 0.007 & & 0.031 & & 0.025 & \\
\hline & [0.058] & & {$[0.023]$} & & [0.021] & \\
\hline NO2*interaction var. & 0.006 & & -0.028 & & -0.065 & \\
\hline & [0.022] & & {$[0.023]$} & & [0.063] & \\
\hline $\mathrm{O} 3$ & -0.032 & -0.034 & -0.002 & 0.006 & 0.005 & 0.011 \\
\hline & [0.043] & [0.040] & {$[0.016]$} & {$[0.014]$} & [0.015] & [0.013] \\
\hline O3*interaction var. & 0.018 & 0.021 & 0.024 & 0.016 & 0.028 & 0.009 \\
\hline & [0.015] & {$[0.014]$} & {$[0.017]$} & {$[0.016]$} & [0.044] & [0.039] \\
\hline
\end{tabular}

See notes for Tables 3 and 4. 
Table 6: Effects of Pollution on Infant Mortality, Conditional on Birth Weight and Gestation, Time Units=Weeks.

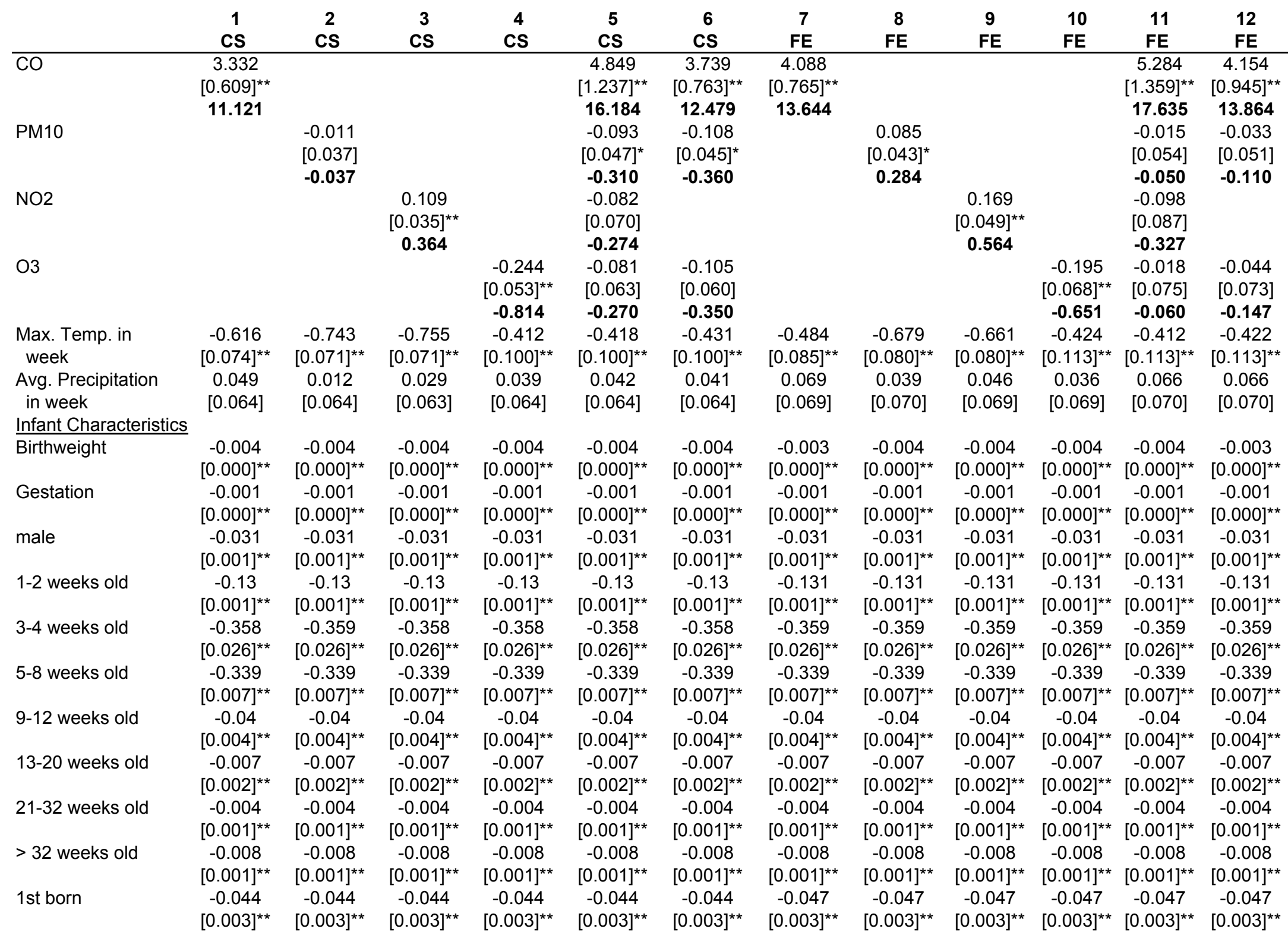


Table 6: Effects of Pollution on Infant Mortality, Conditional on Birth Weight and Gestation, Time Units=Weeks. (continued)

\begin{tabular}{|c|c|c|c|c|c|c|c|c|c|c|c|c|}
\hline & $\begin{array}{c}1 \\
C S\end{array}$ & $\begin{array}{c}2 \\
C S\end{array}$ & $\begin{array}{c}3 \\
\mathrm{CS}\end{array}$ & $\begin{array}{c}4 \\
\mathrm{CS}\end{array}$ & $\begin{array}{c}5 \\
\mathrm{CS}\end{array}$ & $\begin{array}{c}6 \\
\mathrm{CS}\end{array}$ & $\begin{array}{r}7 \\
\text { FE }\end{array}$ & $\begin{array}{r}8 \\
\text { FE }\end{array}$ & $\begin{array}{c}9 \\
\text { FE }\end{array}$ & $\begin{array}{r}10 \\
\text { FE }\end{array}$ & $\begin{array}{r}11 \\
\text { FE }\end{array}$ & $\begin{array}{l}12 \\
\text { FE }\end{array}$ \\
\hline \multirow[t]{2}{*}{ 2nd born } & -0.021 & -0.021 & -0.021 & -0.021 & -0.021 & -0.021 & -0.023 & -0.023 & -0.023 & -0.023 & -0.023 & -0.023 \\
\hline & {$[0.002]^{\star *}$} & {$[0.002]^{\star *}$} & {$[0.002]^{\star *}$} & {$[0.002]^{\star *}$} & {$[0.002]^{\star *}$} & {$[0.002]^{* *}$} & {$[0.002]^{\star *}$} & {$[0.002]^{* *}$} & {$[0.002]^{* *}$} & {$[0.002]^{* *}$} & {$[0.002]^{\star *}$} & {$[0.002]^{\star *}$} \\
\hline \multirow[t]{2}{*}{ 3rd born } & -0.013 & -0.013 & -0.013 & -0.013 & -0.013 & -0.013 & -0.014 & -0.014 & -0.014 & -0.014 & -0.014 & -0.014 \\
\hline & {$[0.003]^{\star *}$} & {$[0.003]^{\star \star}$} & {$[0.003]^{\star \star}$} & {$[0.003]^{\star *}$} & {$[0.003]^{\star *}$} & {$[0.003]^{\star *}$} & {$[0.003]^{\star *}$} & {$[0.003]^{\star \star}$} & {$[0.003]^{* *}$} & {$[0.003]^{\star *}$} & {$[0.003]^{\star \star}$} & {$[0.003]^{* *}$} \\
\hline \multicolumn{13}{|c|}{ Mother Characteristics } \\
\hline \multirow[t]{2}{*}{ Black } & -0.011 & -0.01 & -0.011 & -0.011 & -0.012 & -0.012 & 0.001 & 0.001 & 0.001 & 0.001 & 0.001 & 0.001 \\
\hline & {$[0.003]^{\star *}$} & {$[0.003]^{\star \star}$} & {$[0.003]^{\star *}$} & {$[0.003]^{\star *}$} & {$[0.003]^{\star *}$} & {$[0.003]^{\star *}$} & [0.003] & [0.003] & [0.003] & {$[0.003]$} & [0.003] & {$[0.003]$} \\
\hline Hispanic & {$[0.002]^{* *}$} & {$[0.002]^{\star *}$} & {$[0.002]^{\star *}$} & {$[0.002]^{* *}$} & {$[0.002]^{* *}$} & {$[0.002]^{* *}$} & {$[0.002]^{* *}$} & {$[0.002]^{\star *}$} & {$[0.002]^{* *}$} & {$[0.002]^{* *}$} & {$[0.002]^{\star *}$} & {$[0.002]^{\star *}$} \\
\hline \multirow[t]{2}{*}{ Asian } & -0.013 & -0.013 & -0.013 & -0.013 & -0.013 & -0.013 & -0.01 & -0.01 & -0.01 & -0.01 & -0.01 & -0.01 \\
\hline & {$[0.003]^{* *}$} & {$[0.003]^{* *}$} & {$[0.003]^{\star *}$} & {$[0.003]^{* *}$} & {$[0.003]^{* *}$} & {$[0.003]^{\star *}$} & {$[0.003]^{* *}$} & {$[0.003]^{\star *}$} & {$[0.003]^{* *}$} & {$[0.003]^{* *}$} & {$[0.003]^{\star *}$} & {$[0.003]^{* *}$} \\
\hline \multirow[t]{2}{*}{ Other Race } & -0.007 & -0.007 & -0.007 & -0.007 & -0.007 & -0.007 & -0.005 & -0.005 & -0.005 & -0.005 & -0.005 & -0.005 \\
\hline & [0.008] & [0.008] & [0.008] & [0.008] & [0.008] & [0.008] & [0.008] & [0.008] & [0.008] & [0.008] & [0.008] & [0.008] \\
\hline \multirow[t]{2}{*}{ Married } & 0.004 & 0.004 & 0.004 & 0.004 & 0.004 & 0.004 & 0.003 & 0.004 & 0.003 & 0.004 & 0.003 & 0.003 \\
\hline & [0.003] & [0.003] & [0.003] & [0.003] & [0.003] & 03] & [0.003] & [0.003] & [0.003] & [0.003] & [0.003] & [0.003] \\
\hline \multirow[t]{2}{*}{ Foreign Born } & -0.021 & -0.02 & -0.021 & -0.021 & -0.021 & -0.021 & -0.021 & -0.021 & -0.021 & -0.021 & -0.021 & -0.021 \\
\hline & {$[0.002]^{* *}$} & {$[0.002]^{\star *}$} & {$[0.002]^{\star *}$} & {$[0.002]^{* *}$} & {$[0.002]^{\star *}$} & {$[0.002]^{* *}$} & {$[0.002]^{* *}$} & {$[0.002]^{* *}$} & {$[0.002]^{* *}$} & {$[0.002]^{* *}$} & {$[0.002]^{* *}$} & {$[0.002]^{\star *}$} \\
\hline \multirow{3}{*}{$\begin{array}{l}\text { Parents of } \\
\text { Different Race } \\
\text { HS Graduate }\end{array}$} & {$[0.002]^{* *}$} & {$[0.002]^{\star *}$} & {$[0.002]^{\star *}$} & {$[0.002]^{* *}$} & {$[0.002]^{* *}$} & {$[0.002]^{* *}$} & {$[0.002]^{* *}$} & {$[0.002]^{\star *}$} & {$[0.002]^{* *}$} & {$[0.002]^{\star *}$} & {$[0.002]^{\star *}$} & {$[0.002]^{\star *}$} \\
\hline & -0.008 & -0.008 & -0.008 & -0.008 & -0.008 & -0.008 & -0.009 & -0.009 & -0.009 & -0.009 & -0.009 & -0.009 \\
\hline & {$[0.002]^{* *}$} & {$[0.002]^{\star *}$} & {$[0.002]^{\star *}$} & {$[0.002]^{* *}$} & {$[0.002]^{* *}$} & {$[0.002]^{* *}$} & {$[0.002]^{* *}$} & {$[0.002]^{\star *}$} & {$[0.002]^{\star *}$} & {$[0.002]^{\star *}$} & {$[0.002]^{\star *}$} & {$[0.002]^{\star *}$} \\
\hline \multirow[t]{2}{*}{ Some College } & -0.013 & -0.013 & -0.013 & -0.013 & -0.013 & -0.013 & -0.015 & -0.015 & -0.015 & -0.015 & -0.015 & -0.015 \\
\hline & {$[0.003]^{\star *}$} & {$[0.003]^{\star *}$} & {$[0.003]^{\star *}$} & {$[0.003]^{* *}$} & {$[0.003]^{\star *}$} & $03]^{* *}$ & {$[0.003]^{* *}$} & {$[0.003]^{* *}$} & {$[0.003]^{* *}$} & {$[0.003]^{* *}$} & {$[0.003]^{\star *}$} & {$[0.003]^{\star *}$} \\
\hline \multirow[t]{2}{*}{ College Grad. } & -0.015 & -0.015 & -0.015 & -0.015 & -0.015 & -0.015 & -0.019 & -0.019 & -0.019 & -0.019 & -0.019 & -0.019 \\
\hline & {$[0.003]^{* *}$} & {$[0.003]^{* *}$} & {$[0.003]^{\star *}$} & {$[0.003]^{\star *}$} & {$[0.003]^{* *}$} & {$[0.003]^{* *}$} & {$[0.003]^{\star *}$} & {$[0.003]^{\star *}$} & {$[0.003]^{* *}$} & {$[0.003]^{\star *}$} & {$[0.003]^{\star *}$} & {$[0.003]^{* *}$} \\
\hline \multirow{2}{*}{$\begin{array}{l}\text { Parents Diff. } \\
\text { Education }\end{array}$} & 0.002 & 0.002 & 0.002 & 0.002 & 0.002 & 0.002 & 0.002 & 0.002 & 0.002 & 0.002 & 0.002 & 0.002 \\
\hline & [0.002] & [0.002] & [0.002] & [0.002] & [0.002] & $.002]$ & [0.002] & [0.002] & [0.002] & [0.002] & [0.002] & [0.002] \\
\hline \multirow[t]{2}{*}{19 to 25} & -0.011 & -0.011 & -0.011 & -0.011 & -0.011 & -0.011 & -0.011 & -0.011 & -0.011 & -0.011 & -0.011 & -0.011 \\
\hline & {$[0.003]^{* *}$} & {$[0.003]^{\star *}$} & {$[0.003]^{\star *}$} & {$[0.003]^{\star *}$} & {$[0.003]^{* *}$} & {$[0.003]^{* *}$} & {$[0.003]^{\star *}$} & {$[0.003]^{\star *}$} & {$[0.003]^{\star *}$} & {$[0.003]^{\star *}$} & {$[0.003]^{* *}$} & {$[0.003]^{\star *}$} \\
\hline \multirow[t]{2}{*}{26 to 30} & -0.018 & -0.018 & -0.018 & -0.018 & -0.018 & -0.018 & -0.019 & -0.019 & -0.019 & -0.019 & -0.019 & -0.019 \\
\hline & {$[0.003]^{* *}$} & {$[0.003]^{\star *}$} & {$[0.003]^{\star \star}$} & {$[0.003]^{\star *}$} & {$[0.003]^{* *}$} & {$[0.003]^{* *}$} & {$[0.003]^{\star *}$} & {$[0.003]^{\star *}$} & {$[0.003]^{\star *}$} & {$[0.003]^{\star *}$} & {$[0.003]^{* *}$} & {$[0.003]^{\star *}$} \\
\hline \multirow[t]{2}{*}{31 to 35} & -0.02 & -0.02 & -0.02 & -0.02 & -0.02 & -0.02 & -0.022 & -0.022 & -0.022 & -0.022 & -0.022 & -0.022 \\
\hline & {$[0.004]^{* *}$} & {$[0.004]^{\star *}$} & {$[0.004]^{\star *}$} & {$[0.004]^{\star *}$} & {$[0.004]^{* *}$} & {$[0.004]^{* *}$} & {$[0.004]^{\star *}$} & {$[0.004]^{\star *}$} & {$[0.004]^{\star *}$} & {$[0.004]^{\star *}$} & {$[0.004]^{* *}$} & {$[0.004]^{\star *}$} \\
\hline \multirow[t]{2}{*}{$>36$} & -0.014 & -0.013 & -0.013 & -0.014 & -0.014 & -0.014 & -0.015 & -0.015 & -0.015 & -0.015 & -0.015 & -0.015 \\
\hline & {$[0.004]^{* *}$} & {$[0.004]^{\star *}$} & {$[0.004]^{\star \star}$} & {$[0.004]^{\star *}$} & {$[0.004]^{* *}$} & {$[0.004]^{* *}$} & {$[0.004]^{\star *}$} & {$[0.004]^{\star *}$} & {$[0.004]^{\star *}$} & {$[0.004]^{\star *}$} & {$[0.004]^{* *}$} & {$[0.004]^{\star *}$} \\
\hline $\begin{array}{l}\text { prenatal care 1st } \\
\text { trimester }\end{array}$ & {$[0.002]^{* *}$} & {$[0.002]^{\star *}$} & {$[0.002]^{\star *}$} & {$[0.002]^{* *}$} & {$[0.002]^{* *}$} & {$[0.002]^{\star *}$} & {$[0.002]^{* *}$} & {$[0.002]^{\star *}$} & {$[0.002]^{* *}$} & {$[0.002]^{* *}$} & {$[0.002]^{\star *}$} & {$[0.002]^{* *}$} \\
\hline Observations & 149197 & 149197 & 149197 & 149197 & 149197 & 149197 & 149197 & 149197 & 149197 & 149197 & 149197 & 149197 \\
\hline R-squared & 0.49 & 0.49 & 0.49 & 0.49 & 0.49 & 0.49 & 0.49 & 0.49 & 0.49 & 0.49 & 0.49 & 0.49 \\
\hline
\end{tabular}

See Table 3 notes. Figures in bold indicate the number of deaths per 100,000 that would be saved by a one unit reduction in the pollutant. 
Table 7: Alternative Specifications of the Table 6 Weekly Hazard Model, Zipcode Fixed Effects Models

\begin{tabular}{|c|c|c|c|c|c|c|c|c|c|c|c|c|}
\hline & $\begin{array}{c}1 \\
15 X \text { non } \\
\text { deaths }\end{array}$ & $\begin{array}{c}2 \\
15 X \text { non } \\
\text { deaths }\end{array}$ & $\begin{array}{c}3 \\
\text { No } \\
\text { weather }\end{array}$ & $\begin{array}{c}4 \\
\text { No } \\
\text { weather }\end{array}$ & $\begin{array}{c}5 \\
\text { zip-year fe }\end{array}$ & $\begin{array}{c}6 \\
\text { zip-year } \\
\text { fe }\end{array}$ & $\begin{array}{c}7 \\
\text { Drop 1st } \\
\text { wk }\end{array}$ & $\begin{array}{c}8 \\
\text { Drop 1st } \\
\text { wk }\end{array}$ & $\begin{array}{c}9 \\
\text { 10-mile } \\
\text { sample }\end{array}$ & $\begin{array}{c}10 \\
10-\text { mile } \\
\text { sample }\end{array}$ & $\begin{array}{c}11 \\
\text { time unit } \\
\text { is month }\end{array}$ & $\begin{array}{c}12 \\
\text { time unit } \\
\text { is month }\end{array}$ \\
\hline \multirow[t]{3}{*}{$\mathrm{CO}$} & 2.209 & 1.721 & 5.607 & 4.095 & 5.616 & 4.187 & 6.26 & 4.549 & 4.374 & 3.988 & 3.21 & 4.61 \\
\hline & {$[0.587]^{\star *}$} & {$[0.405]^{\star *}$} & {$[1.355]^{\star *}$} & {$[0.947]^{\star *}$} & {$[1.465]^{\star *}$} & {$[0.991]^{* *}$} & {$[1.409]^{* *}$} & {$[0.979]^{\star *}$} & {$[1.207]^{\star *}$} & {$[0.891]^{* *}$} & {$[1.506]^{*}$} & {$[1.173]^{\star *}$} \\
\hline & 19.660 & 15.317 & 18.713 & 13.667 & 18.744 & 13.974 & 17.981 & 13.067 & 14.598 & 13.310 & 10.713 & 15.386 \\
\hline \multirow[t]{3}{*}{ PM10 } & 0.000 & -0.007 & -0.026 & -0.051 & -0.008 & -0.031 & -0.005 & -0.032 & -0.082 & -0.082 & 0.129 & 0.166 \\
\hline & [0.024] & [0.022] & [0.053] & [0.050] & [0.057] & [0.054] & [0.056] & [0.053] & [0.057] & [0.053] & [0.089] & {$[0.080]^{*}$} \\
\hline & 0.000 & & -0.087 & -0.170 & -0.027 & -0.103 & -0.014 & -0.092 & -0.274 & -0.274 & 0.431 & 0.554 \\
\hline \multirow[t]{3}{*}{ NO2 } & -0.042 & & -0.131 & & -0.124 & & -0.148 & & -0.04 & & 0.144 & \\
\hline & [0.038] & & [0.087] & & [0.096] & & [0.092] & & [0.086] & & [0.121] & \\
\hline & -0.374 & & -0.437 & & -0.414 & & -0.494 & & -0.134 & & 0.481 & \\
\hline \multirow[t]{3}{*}{$\mathrm{O} 3$} & 0.007 & -0.004 & -0.216 & -0.257 & -0.007 & -0.04 & -0.021 & -0.061 & -0.001 & -0.015 & -0.088 & -0.056 \\
\hline & [0.032] & [0.031] & {$[0.059]^{\star *}$} & {$[0.055]^{\star *}$} & {$[0.080]$} & {$[0.078]$} & {$[0.076]$} & {$[0.075]$} & {$[0.078]$} & {$[0.077]$} & {$[0.095]$} & {$[0.092]$} \\
\hline & 0.062 & -0.036 & -0.721 & -0.858 & -0.023 & -0.134 & -0.060 & -0.175 & -0.003 & -0.050 & -0.294 & -0.187 \\
\hline Observations & 397695 & 397695 & 149197 & 149197 & 149197 & 149197 & 133978 & 133978 & 114573 & 115336 & 149243 & 149243 \\
\hline R-squared & 0.4 & 0.4 & 0.49 & 0.49 & 0.52 & 0.52 & 0.17 & 0.17 & 0.5 & 0.5 & 0.47 & 0.47 \\
\hline
\end{tabular}

Notes: Aside from the variation noted in the column heading, these regressions are otherwise similar to those shown in Table 6 .

See Table 6 notes. 
Table 8: Effects of Pollution on Infant Mortality, Including Cumulative Average Weekly Exposure Zipcode Fixed Effects Models

\begin{tabular}{|c|c|c|c|c|c|c|}
\hline & 1 & 2 & 3 & 4 & 5 & 6 \\
\hline \multirow[t]{3}{*}{$\overline{\mathrm{CO}}$} & 3.301 & & & & 5.759 & 3.692 \\
\hline & {$[0.773]^{* *}$} & & & & {$[1.410]^{\star *}$} & {$[0.984]^{* *}$} \\
\hline & 11.017 & & & & 19.221 & 12.322 \\
\hline \multirow[t]{3}{*}{ CO cumulative } & 0.346 & & & & -0.287 & 0.151 \\
\hline & {$[0.156]^{*}$} & & & & [0.278] & [0.197] \\
\hline & 0.115 & & & & -0.096 & 0.051 \\
\hline \multirow[t]{3}{*}{ PM10 } & & 0 & & & -0.048 & -0.088 \\
\hline & & [0.045] & & & [0.055] & [0.053] \\
\hline & & 0.000 & & & -0.160 & -0.294 \\
\hline \multirow[t]{3}{*}{ PM10 cumulative } & & 0.034 & & & 0.021 & 0.029 \\
\hline & & {$[0.010]^{\star *}$} & & & {$[0.012]$} & {$[0.011]^{*}$} \\
\hline & & 0.011 & & & 0.007 & 0.010 \\
\hline \multirow[t]{3}{*}{$\mathrm{NO} 2$} & & & 0.054 & & -0.203 & \\
\hline & & & [0.054] & & {$[0.095]^{*}$} & \\
\hline & & & 0.180 & & -0.678 & \\
\hline \multirow[t]{3}{*}{ NO2 cumulative } & & & 44.162 & & 43.456 & \\
\hline & & & {$[12.294]^{* *}$} & & {$[20.341]^{*}$} & \\
\hline & & & 14.739 & & 14.504 & \\
\hline \multirow[t]{3}{*}{$\mathrm{O} 3$} & & & & -0.198 & 0.033 & -0.019 \\
\hline & & & & {$[0.069]^{\star *}$} & {$[0.077]$} & {$[0.075]$} \\
\hline & & & & -0.661 & 0.110 & -0.063 \\
\hline \multirow[t]{3}{*}{ O3 cumulative } & & & & 1.511 & -20.182 & -8.680 \\
\hline & & & & {$[9.426]$} & {$[12.519]$} & [11.306] \\
\hline & & & & 0.504 & -6.736 & -2.897 \\
\hline Observations & 149197 & 149197 & 149197 & 149197 & 149197 & 149197 \\
\hline R-squared & 0.49 & 0.49 & 0.49 & 0.49 & 0.49 & 0.49 \\
\hline
\end{tabular}

Notes: Aside from the change in time unit from weeks to months, and the addition of the measure of cumulative pollution exposure in Panel $B$, these models have the same form as the fixed effects models in Table 6. See Table 6 notes. 
Table 9: Estimates Using Data Aggregated to Quarterly Level

\begin{tabular}{|c|c|c|c|c|c|c|}
\hline \multirow{2}{*}{\multicolumn{7}{|c|}{$\frac{1}{1 . \text { Dependent Varialbe=Infant Mortality }}$}} \\
\hline & & & & & & \\
\hline \multirow[t]{2}{*}{$\mathrm{CO}$, quarter of death } & 0.047 & & & & 0.015 & 0.030 \\
\hline & {$[0.0307]$} & & & & {$[0.0355]$} & {$[0.0326]$} \\
\hline PM10, quarter of death & & $\begin{array}{l}0.0047^{* * *} \\
{[0.00171}\end{array}$ & & & $\begin{array}{l}0.0036^{\star *} \\
{[0.0016]}\end{array}$ & $\begin{array}{l}0.0040^{* *} \\
{[0.0018]}\end{array}$ \\
\hline NO2, quarter of death & & & $\begin{array}{l}0.0052^{*} \\
{[0.0028]}\end{array}$ & & $\begin{array}{c}0.003 \\
{[0.0031]}\end{array}$ & \\
\hline Ozone, quarter of death & & & & $\begin{array}{c}0.002 \\
{[0.0017]}\end{array}$ & $\begin{array}{c}0.000 \\
{[0.0017]}\end{array}$ & $\begin{array}{c}0.000 \\
{[0.0018]}\end{array}$ \\
\hline \# Observations & 30238 & 30238 & 30238 & 30238 & 30238 & 30238 \\
\hline R-squared & 0.09 & 0.09 & 0.09 & 0.09 & 0.09 & 0.09 \\
\hline \multicolumn{7}{|c|}{ 2. Dependent Varialbe=Low Birthweight } \\
\hline $\mathrm{CO}$, quarter of birth & $\begin{array}{c}0.367 \\
{[0.3225]}\end{array}$ & & & & $\begin{array}{l}0.7077^{\star *} \\
{[0.3324]}\end{array}$ & $\begin{array}{l}0.5808^{*} \\
{[0.3118]}\end{array}$ \\
\hline PM10, quarter of birth & & $\begin{array}{c}-0.014 \\
{[0.0171]}\end{array}$ & & & $\begin{array}{c}-0.030 \\
{[0.0220]}\end{array}$ & $\begin{array}{c}-0.033 \\
{[0.0205]}\end{array}$ \\
\hline NO2, quarter of birth & & & $\begin{array}{c}0.004 \\
{[0.0244]}\end{array}$ & & $\begin{array}{c}-0.021 \\
{[0.0314]}\end{array}$ & \\
\hline Ozone, quarter of birth & & & & $\begin{array}{c}0.009 \\
{[0.0177]}\end{array}$ & $\begin{array}{c}0.032 \\
{[0.0217]}\end{array}$ & $\begin{array}{c}0.027 \\
{[0.0206]}\end{array}$ \\
\hline \# Observations & 35219 & 35219 & 35219 & 35219 & 35219 & 35219 \\
\hline R-squared & 0.26 & 0.26 & 0.26 & 0.26 & 0.26 & 0.26 \\
\hline \multicolumn{7}{|c|}{ 3. Dependent Varialbe=Gestation $<37$ weeks } \\
\hline $\mathrm{CO}$, quarter of birth & $\begin{array}{c}0.356 \\
{[0.5285]}\end{array}$ & & & & $\begin{array}{c}0.285 \\
{[0.6564]}\end{array}$ & $\begin{array}{c}0.330 \\
{[0.6010]}\end{array}$ \\
\hline PM10, quarter of birth & & $\begin{array}{c}0.013 \\
{[0.0335]}\end{array}$ & & & $\begin{array}{c}0.005 \\
{[0.0384]}\end{array}$ & $\begin{array}{c}0.007 \\
{[0.0384]}\end{array}$ \\
\hline NO2, quarter of birth & & & $\begin{array}{c}0.022 \\
{[0.0373]}\end{array}$ & & $\begin{array}{c}0.008 \\
{[0.0469]}\end{array}$ & \\
\hline Ozone, quarter of birth & & & & $\begin{array}{c}0.001 \\
{[0.0298]}\end{array}$ & $\begin{array}{c}-0.001 \\
{[0.0331]}\end{array}$ & $\begin{array}{c}0.002 \\
{[0.0294]}\end{array}$ \\
\hline \# Observations & 35219 & 35219 & 35219 & 35219 & 35219 & 35219 \\
\hline R-squared & 0.34 & 0.34 & 0.34 & 0.34 & 0.34 & 0.34 \\
\hline \multicolumn{7}{|c|}{ 4. Dependent Varialbe=Fetal Deaths } \\
\hline $\mathrm{CO}$, quarter of birth & $\begin{array}{c}0.037 \\
{[0.1163]}\end{array}$ & & & & $\begin{array}{c}-0.008 \\
{[0.1375]}\end{array}$ & $\begin{array}{c}0.055 \\
{[0.1199]}\end{array}$ \\
\hline PM10, quarter of birth & & $\begin{array}{c}0.002 \\
{[0.0051]}\end{array}$ & & & $\begin{array}{c}-0.003 \\
{[0.0069]}\end{array}$ & $\begin{array}{c}-0.001 \\
{[0.0063]}\end{array}$ \\
\hline NO2, quarter of birth & & & $\begin{array}{c}0.010 \\
{[0.0081]}\end{array}$ & & $\begin{array}{c}0.011 \\
{[0.0120]}\end{array}$ & \\
\hline Ozone, quarter of birth & & & & $\begin{array}{c}0.004 \\
{[0.0059]}\end{array}$ & $\begin{array}{c}0.002 \\
{[0.0072]}\end{array}$ & $\begin{array}{c}0.005 \\
{[0.0070]}\end{array}$ \\
\hline \# Observations & 35219 & 35219 & 35219 & 35219 & 35219 & 35219 \\
\hline R-squared & 0.06 & 0.06 & 0.06 & 0.06 & 0.06 & 0.06 \\
\hline
\end{tabular}

Note: The dependent variable in all cases is events per 1,000 , per quarter. To get rates per 100,000 , multiply by 100 . Robust standard errors in brackets. $A{ }^{*}$ and ${ }^{* *}$ indicate significance at the 5 and $1 \%$ levels, respectively. Specifications are similar to those shown in Tables 3 and 6 and include zipcode fixed effects. 